\title{
La torre sureste del castillo de Santaella (Córdoba). Un ejemplo de arquitectura defensiva medieval ${ }^{1}$
}

\author{
The southeast tower of the castle of Santaella (Cordoba). An example of \\ medieval defensive architecture \\ Javier López Rider* \\ Santiago Rodero Pérez ${ }^{*}$ \\ Recibido: 25/02/2019 - Enviado a Evaluación: 11/03/2019 - Aprobado: 31/08/2019
}

\section{RESUMEN}

El artículo presentado proporciona los resultados obtenidos con motivo de la actividad arqueológica puntual previa a la restauración de la torre sureste del castillo de Santaella, municipio ubicado en el interior de la Campiña cordobesa. Dicha intervención ha sido desarrollada en el año 2015, fruto del planteamiento que el Ayuntamiento de esta localidad inició de cara a la puesta en valor y conservación del patrimonio histórico de su término municipal. Asimismo, se complementa con la información de las recientes intervenciones que se han llevado a cabo tanto en el patio de armas como en la citada torre. Al mismo tiempo, se ha realizado un estudio sobre la historia del conjunto de esta fortaleza a través de las diversas fuentes archivísticas inéditas. Entre ellas, cobran especial relevancia las pertenecientes al ámbito cronológico de los siglos XIII-XV. Con la información extraída de los recursos documentales y los datos emanados de los vestigios, se ha podido elaborar una primera interpretación de la evolución histórica de este castillo medieval, carente actualmente de un análisis pormenorizado.

Palabras clave: Arqueología medieval; Edad Media; Torre; Fortificación; Córdoba.

\begin{abstract}
The article presented provides the results on the occasion of the specific archaeological activity prior to the restoration of the southeast tower of the castle of Santaella, a municipality located inside the Cordovan Campiña. This intervention has been developed in 2015, as a result of the approach that the town hall of this locality affected in order to enhance the value and conservation of the historical heritage. Likewise, it is complemented with the information of the recent interventions that have been carried out both in the parade ground and in the cited tower. At the same time, a study on the history of all this fortress has been carried out through several unpublished archive sources. Among them, those belonging to the chronological scope of the $13^{\text {th }}-15^{\text {th }}$ centuries are especially relevant. With the information extracted from the documentary resources and the data emanating from the vestiges, we have developed a first interpretation of the historical evolution of this medieval castle, currently taking care of a detailed analysis
\end{abstract}

Keywords: Medieval Archeology; Middle Ages; Tower; Fortification; Cordoba.

\section{INTRODUCCIÓN²}

El castillo objeto de estudio se encuentra

en la provincia de Córdoba, concretamente en el corazón de la Campiña y dentro del casco urbano del municipio de Santaella. Su ubica-

\footnotetext{
* Profesor Sustituto Interino del Área de Historia Medieval del Departamento de Ciencias de la Antigüedad y de la Edad Media de la Universidad de Córdoba. ${ }^{\star *}$ Arqueólogo.

1. Este trabajo ha sido realizado en el marco del proyecto de investigación OTRI de la Universidad de Córdoba SAC-12014040, titulado Estudio sobre Santaella y el suroeste de la campiña cordobesa en la Baja Edad Media.

2. Abreviaturas utilizadas: $A C C=$ Archivo de la Catedral de Córdoba; $A D M=$ Archivo Ducal de Medinaceli; $A D P C O=$ Archivo de Diputación Provincial de Córdoba; AGA = Archivo General de Andalucía; AGS = Archivo General de Simancas; AHPCO = Archivo Histórico Provincial de Córdoba; AHV = Archivo Histórico de Viana; AMCO = Archivo Municipal de Córdoba; CCA = Cámara de Castilla; BN = Biblioteca Nacional; Leg. = Legajo; Mrs. = Maravedíes; Ms. = Manuscrito; Perg. = Pergamino; PNCO = Protocolos Notariales de Córdoba; RAH = Real Academia de la Historia; RGS = Registro General del Sello; S.f. = sin folio.
} 
ción está a 245 metros de altura sobre el nivel del mar en la cima de uno de los cerros más importantes del término municipal del citado núcleo poblacional (ver fig. 1). Este, no solamente se caracteriza por tener un espléndido control visual del territorio, sino que también, presenta diversas muestras de la existencia de un permanente poblamiento desde el periodo prehistórico. Al norte de la localidad, limita con el barrio Bajo o de la Villa, sector más antiguo de una población protegida por una muralla de la que, en mayor o menor medida, conserva ciertos lienzos que han sobrevivido desde el periodo medieval hasta hoy día.

En la actualidad, es posible asistir a diferentes actividades de recuperación del patrimonio histórico de este lugar, promovido especialmente por el Ayuntamiento y a través de la financiación de Diputación Provincial. El resultado de este planteamiento ha sido el desarrollo de diversas intervenciones enfocadas fundamentalmente en la adecuación e investigación centrada en el castillo de esta localidad. Precisamente, la información plasmada en este artículo procede de ese programa de valorización patrimonial a través de varias acciones de investigación pluridisciplinar. En primer lugar, se ha llevado a cabo un análisis histórico muy relevante. Para ello, se han rastreado las fuentes escritas medievales inéditas que son susceptibles de ser utilizadas en este estudio, haciendo especial hincapié en las bajomedievales cuyo contenido es mucho más generoso y de extraordinaria riqueza que las árabes. En segundo lugar, también se ha desarrollado una fundamental intervención arqueológica, donde se ha llevado a cabo una excavación en la torre sureste del castillo que es la mejor conservada de todo el entramado arquitectónico. A su vez, se ha hecho un estudio e interpretación de las secuencias estratigráficas identificadas y las estructuras halladas en relación a los resultados obtenidos tanto en 2015 como en actuaciones practicadas posteriormente.

La torre objeto de estudio es de planta cuadrangular y conserva un alzado de tapial sobre una base de sillares de considerable tamaño (ver figs. 2, 3, 4, 6 y 12). Presenta múltiples re- facciones tanto al exterior como al interior, donde la única planta accesible se muestra dividida en dos espacios. Uno cuadrado rematado por una cúpula semiesférica de ladrillo que apoya sobre pechinas; y otro espacio rectangular, de menor tamaño, que se encuentra jalonado por una bóveda de arista y delimitado por un muro con vano adintelado rematado por sillares moldurados a modo de volutas (ver figs. 2, 3, 4, 6 y 12). El proyecto científico de 2015, contemplaba la intervención sobre un área cerrada, que en esencia abarcaba la estancia principal de la mencionada torre sureste del yacimiento en cuestión. En dicha área se situaron 7 sondeos con la idea de documentar la secuencia estratigráfica que aportara datos acerca de la ocupación plurisecular de la torre. Previamente a la intervención directa, se procedió a realizar la topografía de detalle con escáner láser terrestre conforme a las directrices actuales de intervención patrimonial. De acuerdo con los principios de conservación y restauración del patrimonio histórico, cualquier acción de esta índole requiere de un levantamiento que documente con rigurosidad su estado actual. Por ello, la decisión sobre la tecnología a aplicar ha de cumplir con un nivel de exigencia mínimo en consonancia con el interés histórico del monumento, yacimiento o conjunto objeto de estudio. Tras la lectura y tratamientos de los datos obtenidos se procedió a la intervención en campo y a la posterior interpretación histórica de todo el conjunto. En este sentido, la intervención sobre la torre sureste el castillo de Santaella contemplaba como objetivos principales, el levantamiento topográfico de precisión (Escáner Laser Digital), para después llevar a cabo la delineación de detalle de secciones que revelasen el estado geométrico actual de la bóveda, así como del grado de desplome que sufren los lienzos verticales que configuran la estancia. A partir de estas proposiciones, en el transcurrir del proceso de documentación se actuó con la premisa de conservar los enlucidos históricos y desmontar lo estrictamente necesario para conocer la secuencia estratigráfica completa siguiendo aquellas interfacies que rompían los muros o los modificaban. Lógicamente, esta secuencia incluía los depósitos de relleno su- 
perficiales que carecían, en principio y dado su contaminación por materiales actuales, de valor arqueológico. Mientras se desarrollaba esta parte de la investigación, se ha ido vacian- bajomedievales procedentes de numerosos archivos, que han permitido extraer una información inédita de este castillo y enriquecer, junto con los trabajos de campo, los resultados

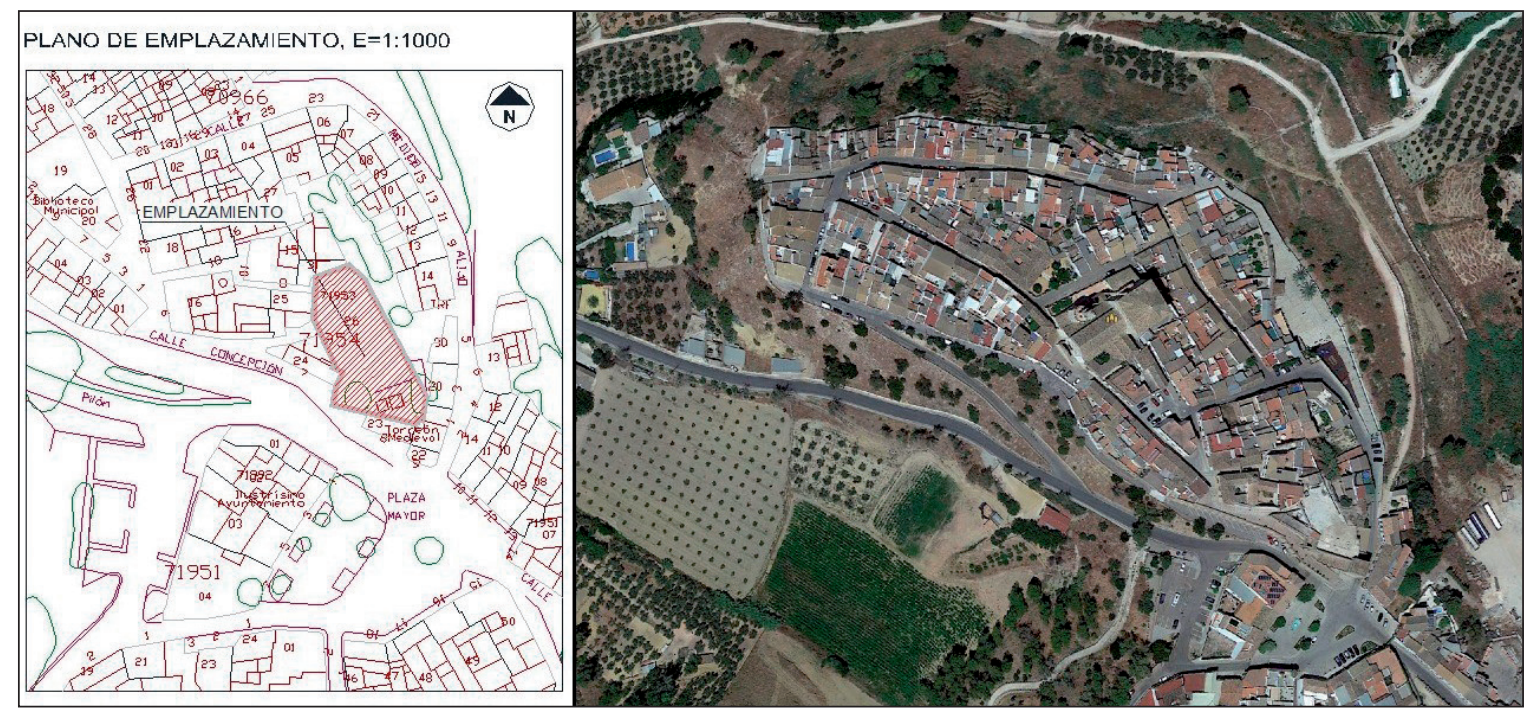

Fig. 1. Emplazamiento y localización del castillo de Santaella (Córdoba). (Elaboración propia de los autores).

do la información de las fuentes archivísticas

\section{CONTEXTO HISTÓRICO}

La identificación de un gran número de yacimientos y la existencia de un buen conjunto de piezas arqueológicas depositadas en el Museo municipal, avalan la importancia que ha tenido Santaella a lo largo de los diferentes siglos. Existen indicios materiales que respaldan la ocupación de esta zona desde el Paleolítico destacando la "Camorra de las Cabezuelas", donde también se han hallado restos del Calcolítico tardío y Plena Edad del Bronce. Del mismo modo, fue interesante el descubrimiento de una cámara sepulcral del Calcolítico en el cortijo de "La Calva", con motivo de las Obras del Plan de Riegos Genil-Cabra (LÓPEZ, 1987: 59-63; GODOY, 1987: 127-131 y VAQUERIZO, 1987: 60-61). Recientemente, en dos intervenciones de 2018, se han localizado en la ladera sur del casco histórico, y en el patio de armas y colindante con la torre sureste finales del presente artículo.

muestras de ocupación adscrita al Bronce Final (BASCÓN, 2018a: 23-24 y BASCÓN, 2018b: 29-36). De obligada mención son los innumerables restos de Cultura Ibérica como cerámicas, esculturas zoomorfas ya sean leones (en especial la famosa "leona de Santaella") o toros ibéricos acaecidos en el término santaellense, por ejemplo, en la Camorra, la Mitra o la Muela (LÓPEZ, 1986: 31-32 y LÓPEZ, 1987: 133 y ss.). El periodo romano está evidenciado no solo a través de los restos arqueológicos, por ejemplo, la reciente recuperación de una columna romana encontrada años atrás en el río Cabra y que estaba depositada en el museo de Priego de Córdoba, sino también a través de testimonios escritos, como la carta del 30 de septiembre de 1760 existente en la Biblioteca Nacional de Madrid (BN, Ms. 2539) donde se habla de vestigios de la citada época (BELTRÁN y MORA, 2000: 13-31). En el Museo municipal se albergan multitud de 


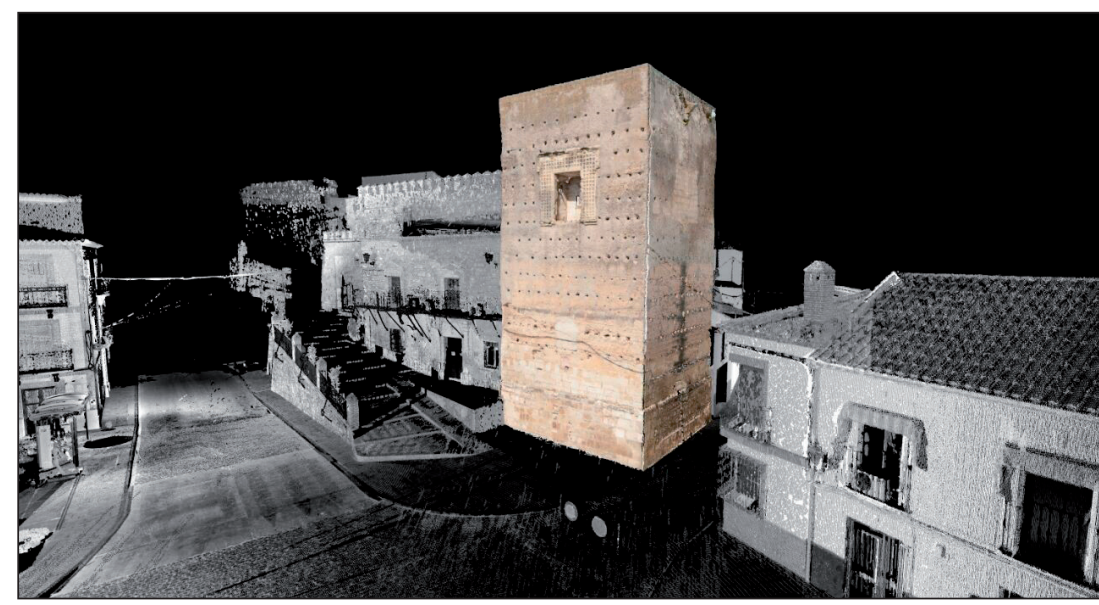

Fig. 2. Torre sureste del castillo de Santaella (Córdoba) a partir del Escáner Laser Digital. (Elaboración propia de los autores).

Bajo), es un área donde la ocupación humana está muy bien documentada. Por tanto, no es nada desdeñable, que durante el periodo musulmán continuara ese poblamiento y se asentara el castillo de Santaella. Los trabajos dedicados a esta obra arquitectónica son prácticamente inexistentes, el motivo de esta falta de profundización en la historia de un inmueble de estas

elementos de esta etapa histórica, como fíbulas, algunos ejemplos de epigrafía romana, fragmentos de estatuas, lucernas, entre muchos otros (LÓPEZ, 1987: 211-248).

Como se puede comprobar, las tierras de este municipio muestran su riqueza desde hace miles de años hasta nuestros días. Incluso para la zona en la que se ha desarrollado la intervención, en la cual se centrará el estudio, mantiene este gran arraigo histórico. Haciendo una breve y concisa revisión historiográfica, aparecen solamente algunos trabajos de finales de los años ochenta, que indican los posibles orígenes poblacionales de esta villa en cuestión. Así, desde "La Sendilla" hasta la zona donde se ha realizado la excavación, es decir el torreón de Santaella, es una zona rica en vestigios del Calcolítico inicial (LÓPEZ, 1986: 18-19) que denotan el surgimiento de un núcleo poblacional desde el tercer al segundo milenio antes de cristo (LÓPEZ, 1987: 38-58). Del 19 de julio al 31 de septiembre de 1993 se llevó a cabo una intervención arqueológica en el actual solar de la Iglesia de Nuestra Señora de la Asunción (IBÁÑ̃EZ, 1993), también próxima al castillo, donde aparecieron algunos restos cerámicos desde el Bronce Final hasta el periodo medieval, documentándose diferentes civilizaciones.

No cabe duda de que el cerro sobre el que se asienta la villa, cuyas denominaciones son diversas (Barrio de la Villa, Villa Vieja o Barrio características radica en la carencia de información de las fuentes documentales de la época. Una consecuencia que afecta a toda la provincia de Córdoba, como bien dejó entrever Alberto León en uno de sus trabajos (LEÓN, 1999: 291-336). A esto habría que sumarle las diferentes modificaciones $y / 0$ destrucciones que han ido sufriendo estas construcciones a lo largo de los siglos, provocando en muchos casos, la pérdida parcial o completa de elementos arquitectónicos originales. Ejemplo de ello, son los castillos de Cabra, Baena, Montoro, Aguilar, Montilla, o nuestro caso, Santaella (LEÓN, 2009: 61-62).

A pesar de ello, algunos eruditos hicieron eco de la existencia del castillo y de su estado de conservación y los elementos que componían su estructura. Según Ramírez de las Casas-Deza, Santaella cuenta con una "antigua fortaleza", situada en lo que llaman "la villa vieja", incluso plasma que ya está derruido y que ha tenido murallas sólidas, una puerta por la parte de la plaza, que era única puesto que el castillo estaba rodeado de barrancos y, por tanto, no era accesible, e incluso que está lleno de aljibes (RAMÍREZ, 1986: 407-409). Por su parte Saraza Murcia, indica que del antiguo castillo se conservan algunos torreones y lienzos de murallas, también confirma que está rodeado de barrancos y que solo tenía una puerta en la plaza reafirmando igualmente la presencia de varios aljibes en su recinto (SARAZA, 1935: 226). 


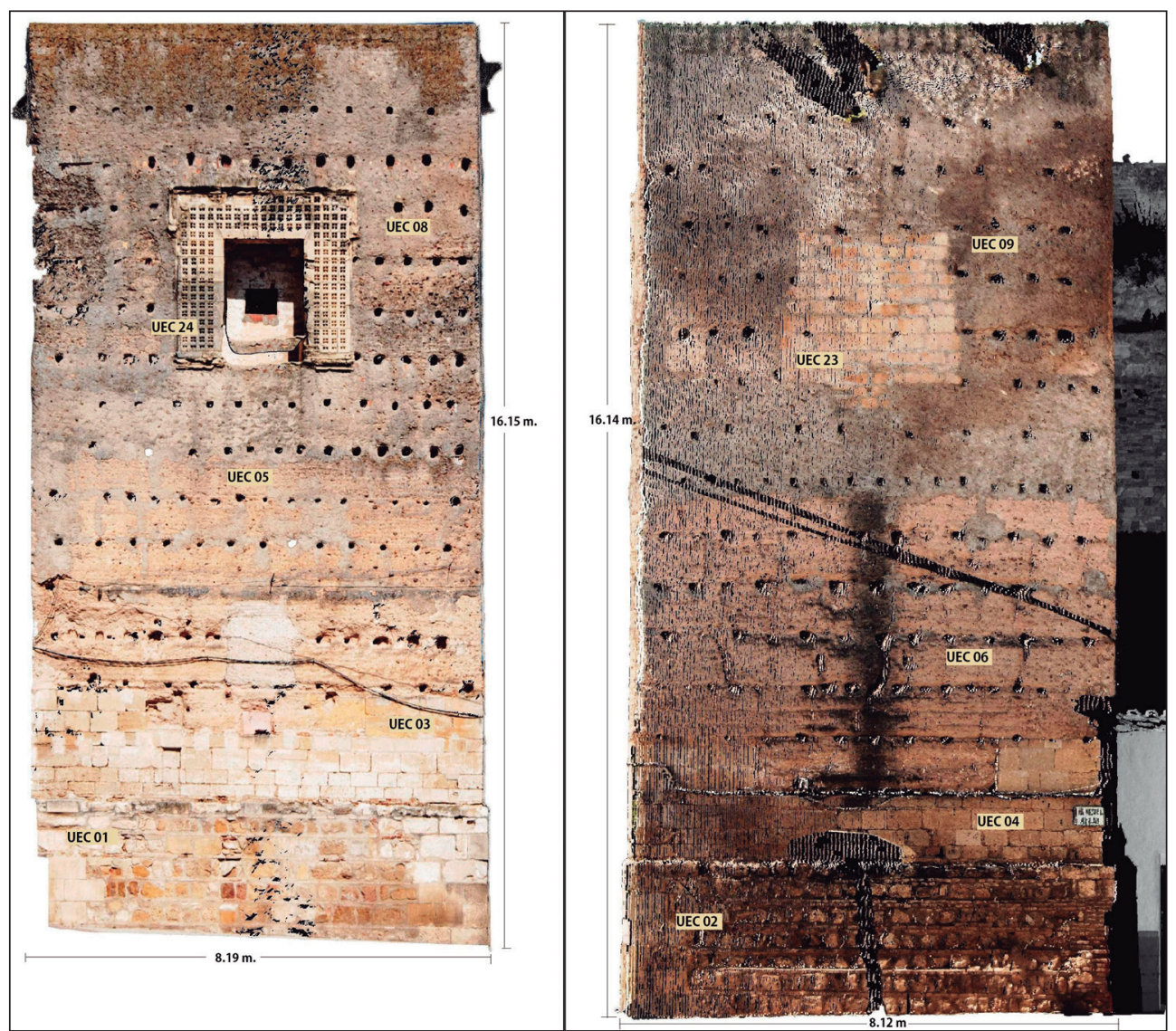

Fig. 3. Alzados de las fachadas sur y este de la torre sureste con las unidades constructivas correspondientes y sus dimensiones. (Elaboración propia de los autores).

Otro dato interesante es el aportado por Mercedes Valverde y Felipe Toledo, al explicar que las construcciones árabes del recinto amurallado que rodea y protege la villa, que ocupa las tres cuartas partes de la población, están edificados con materiales del cerro de la Muela, lugar que como se ha indicado, contiene vestigios desde la época del Bronce. Además, añaden que hay una puerta en recodo, tradicional en época islámica y una poderosa torre (VALVERDE y TOLEDO, 1985: 239-241) que, por otra parte, se trata de la protagonista de este trabajo (ver figs. 2, 3 y 4).

Teniendo en cuenta los datos proporcionados hasta el momento, se manifiesta la carencia de estudios que aporten información del castillo y la torre. Al igual que ocurre en el resto de la provincia cordobesa, donde gran parte de la información de las fortalezas y poblamiento procede de testimonios escritos (CÓRDOBA,
2004: 123), para Santaella la situación no difiere mucho.

\subsection{Etapa musulmana}

Durante el periodo islámico, las noticias acerca de la villa o el castillo son prácticamente inexistentes. Al menos es posible saber de su presencia gracias a las obras de Al-Idrisí donde aparece el topónimo Shant Yala o Sant-lella (AL-IDRISI, 2009-2010: 94; 1989: 86-87 y 230 y ARJONA, 1982b: 29-44). Proporciona información acerca de su ubicación y distancia respecto a otros lugares que coincide aproximadamente con los parámetros actuales. Por ejemplo, en su trabajo sobre los caminos del siglo XII hace la siguiente descripción: "entre Córdoba y Santyala (Santaella) hay veinticinco millas; entre el castillo de Santaella y Lucena hay dieciséis millas (...) del castillo de Santaella al castillo de Osuna (Usuna) hay veinte millas (...)" (AL-IDRISI, 1989: 86-87). 


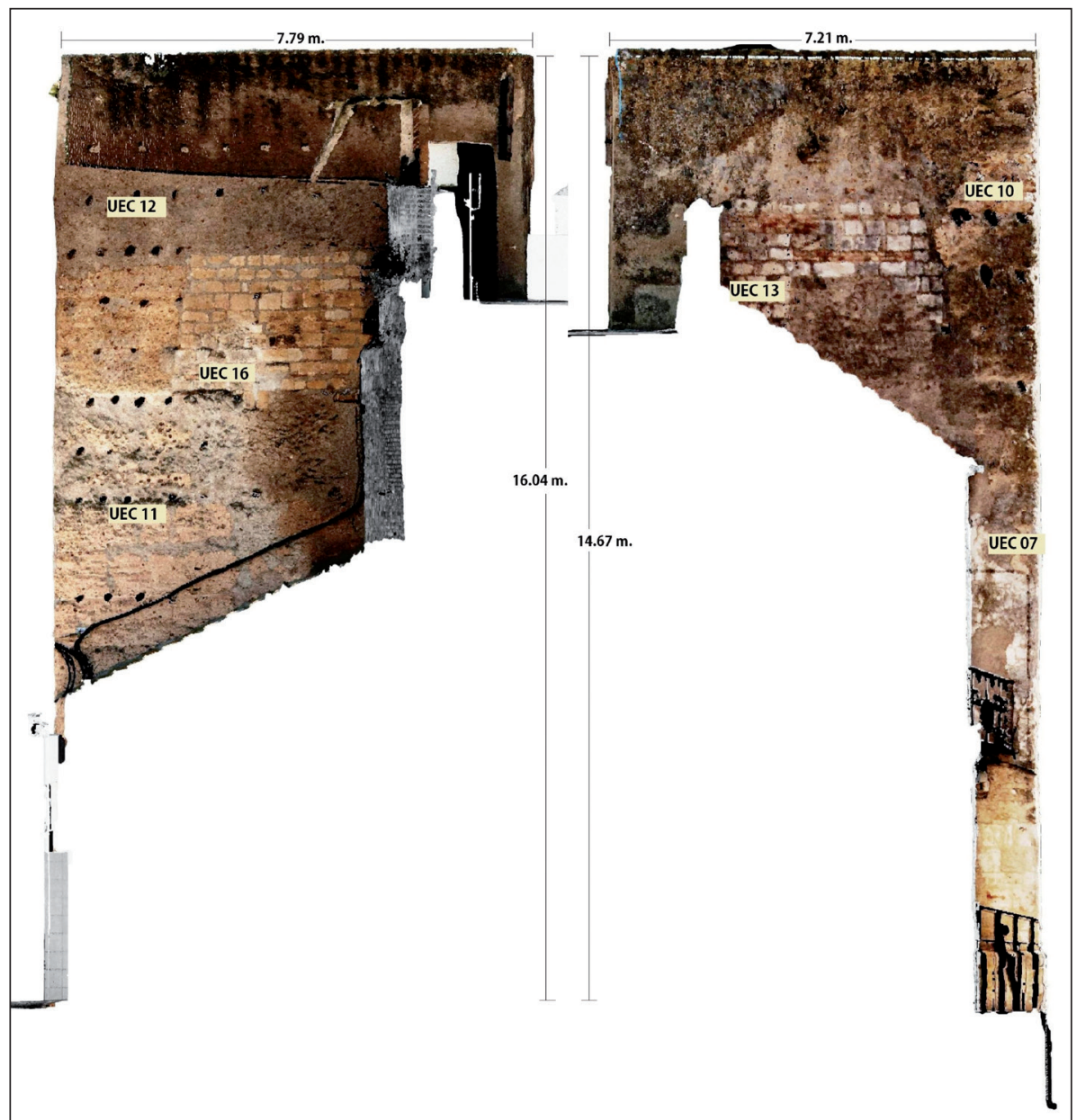

Fig. 4. Alzados de las fachadas norte y oeste de la torre sureste con identificación de sus unidades constructivas y sus medidas. (Elaboración propia de los autores).

Del mismo modo, en su otra obra menciona que "en las proximidades de Bulay (Poley o Aguilar) se halla el hisn de Shant Yala, construido sobre un terreno árido; el agua se encuentra lejos, y desde ella hasta Istiya (Écija) en el occidente, hay quice millas" (AL-IDRISI, 2009-2010: 94). Como apuntó Arjona Castro, este castillo posiblemente estaría incluido en el iqlim de Uliyat Kanbaniya, ya que la distribución jurisdiccional almohade se mantuvo una vez que se produjo la victoria cristiana (ARJONA, 1982b: 90-91; 1982a: 237). Poco después de la conquista fernandina, existen algunos datos que confirman el pasado islámico de este recinto fortificado. Gracias a esa pleitesía del monarca castellano, se permitió que tanto musulmanes como cristianos vivieran en el interior de los mismos recintos fortificados, así en Santaella, se ha documentado la existencia de una aljama islámica donde su alcayat recibía el nombre de Aben Carim y compartía el cargo junto a un alcaide cristiano llamado Ordón u Ordoño Pérez, ambos en 1258 (NIETO, 1984: 187). Años después, concretamente en 1263, aparece Hamet Aben Xait como alcayat de este lugar (NIETO, 1986: 46-50). A partir de este año, lo normal es encontrar alcaides cristianos puesto que el 1 de abril de 1263, Alfonso X impuso que fuera el concejo de Córdoba quien nombrase los alcaldes de las villas y aldeas de su término, descartando lógicamente a los de origen musulmán (NIETO, 1986: 49).

\subsection{Periodo cristiano}

Una vez conquistada la ciudad de Córdoba por Fernando III el 29 de junio 1236, el siguien- 
te paso fue hacerlo también con la Campiña (CABRERA, 1995: 316-317). La Crónica General indica que, a través de pactos, entre musulmanes y cristianos, se concedió a este rey la inmensa mayoría de los castillos y villas de la Campiña y valle del Guadalquivir, incluyendo Santaella (COSTAS, 2001: 102). La adquisición del castillo debió hacerse entre febrero de 1240 y marzo de 1241. A partir de entonces, la información acerca de su población y castillo será más abundante, apareciendo noticias muy sugerentes que permiten profundizar en su historia, puesto que la administración real comenzó a emanar innumerables documentos que informan de muchos aspectos del mismo. Para una mejor comprensión de la evolución histórica del castillo, se irá plasmando lo que se ha podido localizar a través de cada uno de los siglos de la etapa bajomedieval.

\section{A) Siglo XIII}

Desde esta centuria, las referencias documentales hablan más de la propia villa que de su castillo. Un aspecto totalmente comprensible, ya que, a partir de la segunda mitad del citado siglo, aquellos castillos que pasaron al dominio cristiano eran renovados o reparados. Algunos se ubicaban en cerros que ostentaran una buena altura para su defensa y un adecuado control visual, teniendo siempre en cuenta la existencia de núcleos de población a los que había que proteger. Aquí es donde entra en juego la estrecha relación entre villa y castillo, que en el caso de Santaella se aplica perfectamente. Este es uno de los motivos que inciden en que existan más datos acerca de la villa que de la propia fortaleza, puesto que la primera provoca que se origine la segunda; sin olvidar que, en su origen, probablemente se trate más de una ocupación humana con murallas y un pequeño reducto militar (MALPICA, 2003: 34), para con el tiempo forjar un auténtico castillo. También hay que destacar la idea de su mención como villa, es decir, desde finales del siglo XIII aparece como tal, y no como aldea y torre, que fue, por ejemplo, el caso de Cañete de las Torres (MORENA, LEÓN y RODERO, 2007: 38 y ss.). Esto explica que el objetivo del castillo de Santaella, al igual que muchos otros, fuese

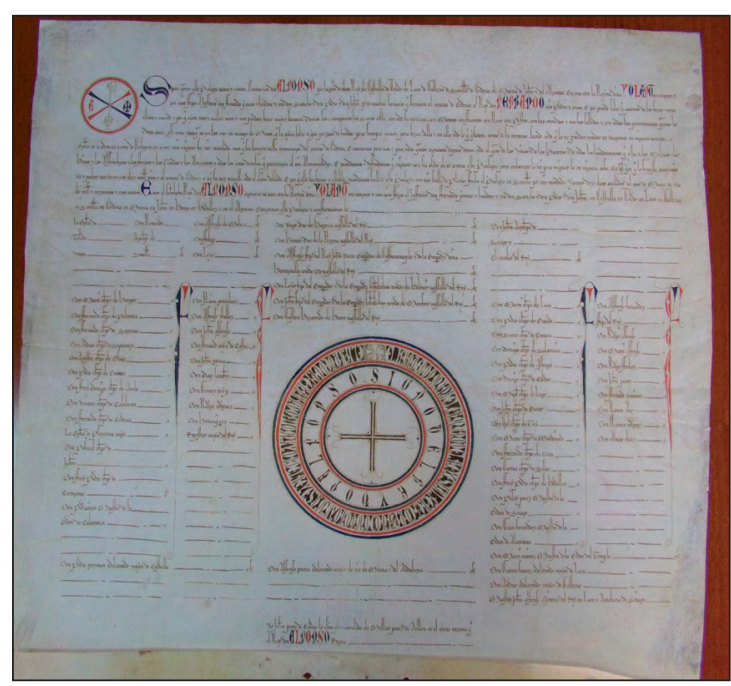

Fig. 5. Privilegio rodado de Alfonso X el Sabio, donde hace entrega de la villa de Santaella al concejo de Córdoba. (Realizada por los autores).

simplemente la salvaguarda de los vecinos de su respectiva villa en momentos de inestabilidad y guerra (SÁNCHEZ y VALOR, 2004: 35), sirviéndose de ellos como base militar los diferentes ejércitos de ocupación o defensa en la cercana frontera (LÓPEZ, 2016: 23-25). Aplicando esta idea, se comprende que en algunas referencias documentales se cite la villa solamente. Por ejemplo, cuando Alfonso X el Sabio entrega Santaella a la jurisdicción del Reino de Córdoba en 1265 (ver fig. 5), se cita solo la villa (1265.03.12, AMCO, Perg. 7, carpeta 6, fol. 1r). Y en 1293, a través del testamento de Domingo García, prior de la Catedral de Córdoba, lega a Martín García y su mujer, una casa en la villa de Santaella, donde vivía Pedro Mínguez, además de otra casa linderos a la anterior, a doña María, suegra del citado Martín García (1293.11.09, ACC, caja R, núm. 108, fol. 1r.). Nuevamente no se cita en ningún momento el castillo, pero sí un incipiente urbanismo intramuros.

No obstante, entre 1258 y 1264 hay constancia de la puesta en marcha de un concejo autónomo en Santaella, con su especial mezcolanza entre musulmanes y cristianos, citándose para el mismo momento alcaldes árabes, mencionados en líneas anteriores, y cristianos (1258.04.30, RAH, colección Salazar y Castro, I-40, fol. 120r-v.; 1263.02.23, ACC, caja N, n. 6, 
s.f.; 1263.02.22, ACC, caja N, n. 4 y n. 36; ACC, Ms. 125, fols. 86v-87v.; NIETO, 1986: 50; GONZÁLEZ, 1991: n. 252; n. 253, n. 260 y n. 261 y LÓPEZ, 2018b: 114). Y precisamente el 12 de marzo de 1265, Alfonso X el Sabio es cuando realiza la comentada entrega de la villa al concejo cordobés, hecho que supone un reconocimiento oficial como un núcleo poblacional de carácter realengo, con una institución concejil e inserto en la jurisdicción del Reino de Córdoba.

\section{B) Siglo XIV}

A través del Ordenamiento de dehesas de Enrique II, se confirma que Santaella era uno de los núcleos que seguían estando poblados (CABRERA, 1976-77: 45). Una población que, con anterioridad a esta disposición normativa, gozaba de diversas viviendas en el casco urbano y limítrofes con el castillo, del que apenas existen datos que nos indiquen alguna nueva información, que es realmente donde se ha llevado la intervención. De este modo, en 1331, Yagües Gil realizó el trueque con Lope Álvarez de un pedazo de casa que tenía en el castillo de Santaella, lindante con otras que ya poseía allí. El intercambio se hizo para que el remanente de agua que se quedaba en el corral del primero pudiese correr hasta el corral del segundo vecino (1331.02.23, ADM, Feria, leg. 18, ramo 5 , n. 1, s.f.). Unos años después, en 1342, Pedro Díaz, alcalde y vecino de Córdoba, vendía a Gil Martínez, alcalde, y a su mujer Sol Fernández, entre otros bienes, "vn solar para faser casas en el dicho castiello de Santa Ella, que se tiene con el adarve e con casas que fueron de Diosdado y con las calles, todo en presçio de 20.000 mrs" (1342.02.01, AHV, L0397, E0004, fol. 1r.). De igual manera para 1399 a la hora de terçia, se celebró una reunión en la plaza del castillo de la villa para tratar sobre ciertas casas de este lugar. Se plasma que el alcaide era don Juan Gil y los escribanos públicos, Alfon Ruiz y Ruy López, todos los cuales formaban parte del concejo de Santaella ${ }^{3}$. Las casas que motivaron tal reunión habían sido propiedad de Juan Fernández Ferrero y su mujer Teresa Martínez y las vendieron, según sus testamen- tos, al Conde de Feria don Gómez Suárez de Figueroa (1394-1430) (MAZO, 1974: 121), que mandó tomar posesión de las mismas a Rodrigo Alfes (LÓPEZ, 2017: tomo I, 431). También hay noticia de que en el primer tercio del siglo XIV el castillo de Santaella dio cobijo en su interior a un cuerpo de caballería (FERNÁNDEZ, 1964: 214).

Gracias a estos datos no solo se aprecia las continuas menciones al castillo, sino que también se confirma que la plaza de armas se mantenía en uso para finales del siglo XIV puesto que la utilizan incluso como punto de encuentro los oficiales concejiles allí asentados. Al mismo tiempo, es posible deducir que parte del castillo se está desmontado para solares de casas desde los años 40 del citado siglo, lo que invita a pensar que el castillo de Santaella estaba perdiendo valor desde un punto de vista militar. Aun así, mantendría un mínimo de estabilidad, ya que el periodo todavía era convulso ante la continua guerra contra los musulmanes. Un claro ejemplo se vislumbra en el apartado económico, donde se construyen torres defensivas en el denominado molino de la torre del Maestre o Ruy Fernández, en el molino de la Rubia o molino de la torre de la casa, todas en término de Santaella (LÓPEZ, 2013: 104-108 y 124-125).

\section{C) Siglo XV}

Para este momento, la consecuencia de la Frontera era una realidad y los documentos de la época manifiestan el aumento de la tensión bélica y la decisión de mantener en buen estado defensivo algunos castillos. Así a través de una real provisión de Enrique III de 1404, se destinan ciertos maravedíes de las imposiciones aplicadas a la carne y al vino hacia el mantenimiento de los muros de la ciudad de Córdoba y castillos de su territorio (LÓPEZ, 2016: 23-25). En esta ocasión, señalan "el adobo e reparamiento de los dichos muros de la dicha cibdat e de los dichos lugares de [Castro del Río] y Santa Ella, pues son puestos por donde en tiempo de guerra, los

3. Juan Gil era alcalde desde, al menos, 1378 según los documentos 1378.03.31. BN, ms. 627, fol. 12r. y 1378.04.03. ms. 627, fol. 12v. 


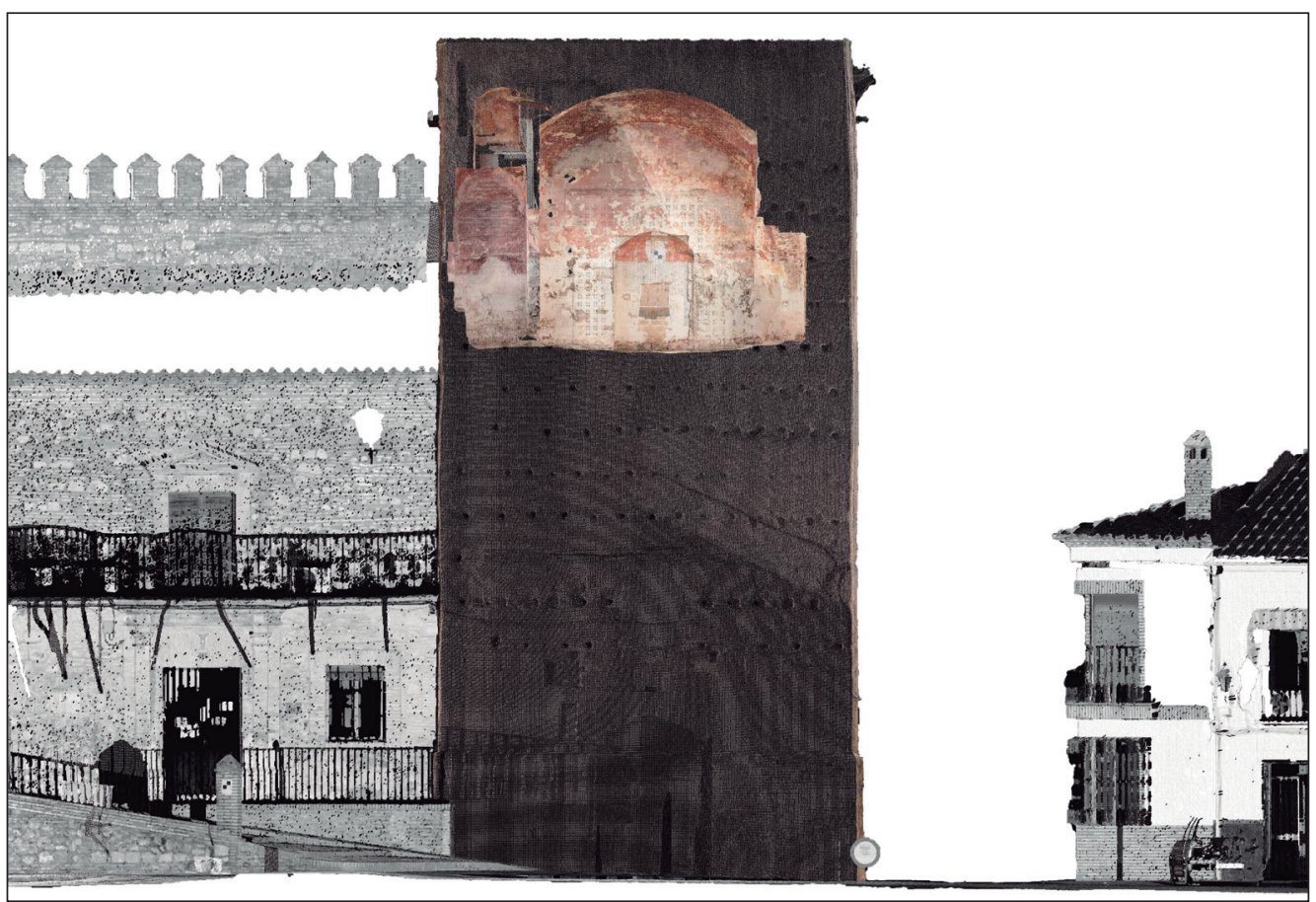

Fig. 6. Imagen con la sección proyectada de la cámara exterior sur de la torre estudiada. (Elaboración propia de los autores).

moros entran en esta tierra a faser mal e daño a esta [cibdat] e toda esta tierra (...)" (LÓPEZ, 2015a: 223). Un año después, en un albalá del mismo monarca, se acuerda que se aplicaran nuevamente las dichas imposiciones, cuya recaudación se dirigirá a la compra del castillo de Almenara, y el dinero sobrante, para las reparaciones necesarias de los muros de Castro del Río y Santaella, puesto que "son castillos fronteros de tierra de moros" (1405.05.20, RAH, Colección Salazar, vol. 32, n 50.866, M-35, fols. 53r-v.). Junto a la conservación de dichos muros, hay constancia de la existencia de una vecindad cada vez más estable y dinámica, donde las viviendas con corrales o cuadras continúan colindantes al castillo en cuestión. Por ejemplo, en 1441, Ruy Fernández vinculó en mayorazgo para su hijo don Gómez de Figueroa, unas casas en Santaella junto a otras que ya poseía fronteras con establo y corral. Estas últimas posiblemente se traten de las ya citadas para el siglo anterior, pues lindaban con el adarve del castillo. Al lado vivían otros vecinos como Andrés y Diego Fernández (1441.01.28, AHV, L0387, E0005, fol. 1r.). Avanzado en el tiempo, no existen referencias acerca del castillo hasta la segunda mitad de la centuria, ni incluso cuando en 1444 la villa de Santaella es entregada por Juan II a don Martín Fernández Portocarrero, señor de Palma del Río hasta 1451 (NIETO, 1986: 50). Habrá que esperar a 1460, donde comienzan a surgir nuevos datos como consecuencia del estallido de la guerra civil castellana entre Enrique IV y el infante don Alfonso (1465-1468). A esta situación tan inestable habría que considerar el posicionamiento de diferentes nobles a favor de una u otra de las facciones enfrentadas en la contienda. Esto produjo la conocida lucha de bandos, que ocuparon los castillos de las villas realengas del área de Córdoba (CARPIO, 2001: 229-230). A favor de Enrique IV estaban el Conde de Cabra, don Martín Alfonso, don Fernando Pérez de Montemayor, don Pedro Venegas, don Luis Portocarrero, señor de Palma y el obispo don Pedro Solier. En contra se situaban don Alfonso Fernández de Córdoba, el alcaide de los Donceles, don Luis Méndez de Sotomayor, señor del Carpio, don Gonzalo Fernández de Córdoba y el apoyo financiero de los conversos situados en la ciudad (RAMíREZ, 1919: 95 y 223). 
Desde 1460, la villa y castillo de Santaella fue ocupada por el señor don Alfonso Fernández de Córdoba (NIETO, 1986: 52), ya que ambos bandos, buscaban encarecidamente reforzar la posición militar y aumentar sus riquezas con las rentas aplicadas en ellas (LEÓN, 2009: 77). En el castillo objeto de estudio, el alcaide fue el caballero veinticuatro, don Fernando de las Infantas, nombrado por el señor de Aguilar durante su dominio en el Reino cordobés, y que se mantuvo, según los propios vecinos, como alcaide durante veinte años, hasta que el conde de Cabra se la quitó en 1474 (LÓPEZ, 2017: tomo II, 651-654). Los vecinos de la población testifican que "fue alcaide mucho tienpo desta villa y hacían lo que él mandaba", incluso en ocasiones que ejercía dicho cargo "de muchos días en la fortaleza desta villa y se hacía en ella cuanto él mandaba, que nadie se lo resistía (...)". Juan García Cabeza, entre otros, vio que era "mucho tiempo alcaide en la fortaleza desta villa por don Alonso de Aguilar, que tenía Córdoba, hasta que el conde de Cabra le hurtó la dicha fortaleza (...)". Y Pedro Ruiz el rubio, en uno de los testimonios más completos, declara "que en tiempo de los movimientos y bandos de Córdoba y su tierra, Fernando de las Infantas tubo por don Alfon de Aguilar ciertos años la fortaleza de esta villa, hasta que el conde de Cabra ge la tomó, y que en aquel tiempo el dicho Fernando de las Infantas mandaba en esta villa lo que quería como alcaide de ella". Sin embargo, la declaración más importante la proporciona Pedro Ruiz Calvo, pues con sus palabras se entiende que allí había un castillo con escasos recursos defensivos y será el Conde de Cabra quien los mejore. Unas reformas que la intervención arqueológica, como se verá más adelante, confirma. Según especifica aquel vecino "más de cuanto vio en esta villa al dicho Fernando de las Infantas, que estovo en ella mucho tienpo e todo cuanto él mandava se fasía, y que entonçes, no avia fecha fortaleza como después que la tomó el conde de Cabra" (LÓPEZ, 2017: tomo II, 651-654). A tenor de la información extraída de las fuentes escritas, la tenencia del castillo estaba en manos de don Alfonso de Aguilar desde 1464 (LEÓN, 2009: 80-81) entregándosela en calidad de alcaide a don Fernando de las Infantas. Otros alcaides de Santaella fueron don Rodrigo de Godoy, don Luis de Godoy y don Juan de Godoy, estos dos últimos para 1479 y 1480 respectivamente (1479.07.06, AGS, RGS, fol. 94r.; RUANO, 1779: 293-294 y CABRERA, 1996: 65).

Fallecido el infante don Alfonso, el rey Enrique IV comenzó a firmar capitulaciones con la idea de recuperar las villas y fortalezas ocupadas. Para ello, empezó indagando acerca del gasto que se llevó a cabo en aquellos castillos tomados por ambos bandos nobiliarios. Su objetivo era devolver a los caballeros el dinero que desembolsaron para el mantenimiento y reparo que hicieron en ellos (incluida Santaella y su castillo), con motivo de los enfrentamientos pasados (1469.06.06, AMCO, C-0007, doc. 03, fol. 1r.). Según la real cédula, el procedimiento que el monarca llevó a cabo consistió en que asistiesen a estas villas con "otros maestros e albañyles e otras dichas personas que dello sepan, e sobre juramento que dellos rescibades, e los tales maestros e albañyes e personas ante vosotros fagan en forma deuida veades las lauores que asy en las dichas villas e logares (...) tasedes e averiquedes los gastos que los dichos caualleros en la lauor dellas fisieron de sus propios dineros" (Ibidem). Una vez que se hubieran realizado los correspondientes pagos, se acordó que el Conde de Cabra devolviera Castro del Río al concejo de Córdoba; mientras que Santaella permanecería en manos del maestre de Santiago don Juan Pacheco y del obispo de Sigüenza don Pedro González de Mendoza. Una vez pasados dos días, derribarían las fortalezas "hasta ponerlas por el suelo" (1469.06.06, AMCO, C-0007, doc. 04, fol. 1r.). Si el Conde de Cabra no las destruye, el obispo de Sigüenza y el maestre de Santiago, entregarían definitivamente Castro del Río y Santaella más cierta suma de maravedíes al concejo cordobés. Si los oficiales de Córdoba tampoco cumplen con su trato, aquellas dos villas y el dinero serían entregados al Conde de Cabra. Una vez cumplido el acuerdo y pasados ocho días, serían igualmente derribados los castillos de Santaella y Castro del Río (1469.06.06, AMCO, C-0007, doc. 06, fol. 1r-2r.). Por fortuna y como era de esperar, el acuerdo no llegó a cumplirse completamente y los problemas sociopolíticos 
obstruyeron la desaparición de estas fortalezas (RAMÍREZ, 1919: 241-242.).

A pesar de que el castillo de Santaella se salvó de su posible destrucción, ni que decir tiene que tuvo que sufrir fuertes estragos en su arquitectura, causadas por las numerosas escaramuzas que libraron ambos bandos. Desgraciadamente, las fuentes documentales no informan de ello. Sin embargo, estas serán más generosas por el hecho que se produjo posteriormente. Como ya se ha indicado en líneas previas, don Fernando de las Infantas será durante varios años alcaide del castillo de Santaella bajo el nombramiento y representación de don Alfonso Fernández de Córdoba. Estando este alcaide allí, se produjo el famoso acontecimiento del 18 de septiembre de 1474 , es decir, el asalto al castillo por parte del hijo del Conde de Cabra, el mariscal de Castilla don Diego Fernández de Córdoba (NIETO, 1986: 59). La notoriedad de este acontecimiento radica en la toma como prisionero de don Gonzalo Fernández de Córdoba (Gran Capitán) y su esposa, doña Isabel de Sotomayor. Este conocido personaje era alcaide de la cercana fortaleza de La Rambla, para la cual llevó a cabo diversas obras valoradas en 340.000 mrs. y que pidió en 1480 que se le abonasen (1480.11.10, AGS, RGS, Leg. 68, fol. 1r-V.). A pesar de no residir en el castillo de Santaella ni ser alcaide de este, fue hecho prisionero por su primo, sin duda, una mera coincidencia puesto que también fue capturado el alcaide de Antequera, don Gome Suárez de Figueroa. Posiblemente se trató de una reunión puntual y el Conde de Cabra aprovechó para aprisionarlos. Según las pesquisas que se hicieron para profundizar en el asalto, entraron con escaleras por los adarves y sorprendieron a todos. De hecho, apenas hubo un enfrentamiento violento (LÓPEZ, 2018a: 280-292). Por ejemplo, así lo testifica Pedro Fernández de Herrera, explicando que "escalaron e subieron por encima de los adarues por escalas e furtaron e entraron e ocuparon la villa de Santaella" (Ibidem: 287). Y según especifican:

"gentes del dicho conde e con don Pedro, obispo de la dicha çibdat, e de Martín Alfonso de Montemayor, señor de Alcabdete, a caballo e a pie armados porfuera (...) entraron e tomaron e ocuparon furtiblemente la villa de Santaella, villa de la dicha çibdad, (...) e tomaron e prendieron e levaron presos della a Gonzalo Fernández de Córdoba, fijo de don Pedro, señor de la casa de Aguylar, e a doña Ysabel de Sotomayor, mujer del dicho Gonçalo Fernández, e les tomaron muchos bienes e oro e plata e joyas e caballos e mulas e armas e otros muchos bienes (...)" (LÓPEZ, 2017: tomo II, 654)

Tomado el castillo por el ya citado mariscal, llevaron al Gran Capitán preso a Baena, metido en una jaula (NIETO, 1986: 60.). Mientras tanto, el Conde de Cabra dejó en Santaella a su hijo don Martín Fernández de Córdoba, que a pesar de los intentos de don Alfonso Fernández de Córdoba, mantuvo en su poder el castillo (QUINTANILLA, 1979: 125-126) y causó la pérdida de la alcaidía de don Fernando de las Infantas. En febrero de 1478, se exigía a don Diego Fernández de Córdoba la entrega de la fortaleza a don Nuño Orejón y su hermano don Gonzalo, quedando de este modo restituida su posesión en manos del concejo de Córdoba (ANDRÉS, 1951: 643). Ahora será la Corona quien seleccione los alcaides que deben tener los castillos realengos de Córdoba, según indica Hernando del Pulgar: "tomaron las fortalezas de Hornachuelos, e de Andúxar, e de los Marmolejos e de la Rambla, e de Santaella, e de Bujalance, e de Montoro, y del Pedroche, e de Castro del Río, e pusieron en ellas por alcaydes a personas pacíficas que las touiesen por ellos" (HERNANDO DEL PULGAR, 1953: 337-338.). Un ejemplo lo encontramos el 6 de julio de 1478, que es cuando la reina, a petición del comendador Frey Luis de Godoy, ordena al concejo de Córdoba que, respetando el acuerdo pactado con sus majestades cuando les entregó los alcázares de Carmona, de los que él era alcaide, a cambio de la tenencia de la villa de Santaella, le asigne por esta lo mismo que paga por cualquier villa y fortaleza de la tierra de Córdoba (RUFO, 1993: 265.). Poco tiempo después, los Reyes Católicos entregan a don Juan de Godoy, hijo del ya citado don Luis de Godoy, el castillo de Santaella (VALVERDE y TOLEDO, 1985: 240.).

A lo largo del siglo XV, el castillo deja de ser un importante bastión militar puesto que apenas aparece en la documentación como 
tal. La inmensa mayoría de las ocasiones, Fernando el Católico se reunirá con sus tropas en la fortaleza de La Rambla, lugar cercano desde el que inicia sus incursiones contra el Reino nazarí. Esto no quiere decir que no siguiese participando en la lucha, de hecho, se documenta su cooperación en las campañas contra Coín, Ronda, Casarabonela, Marbella en 1485 o la batalla de Lucena de 1483 (RAMÍREZ, 1919: 305 y 324.). Aunque no deja de ser un castillo secundario o incluso terciario. La mayor prueba de ello se manifiesta en nuevas referencias documentales. Por un lado, las diversas menciones a nuevas casas, por ejemplo, en 1479 se alude a la posesión de unas viviendas por parte de doña Elvira de Aguilar, hija de don Alfonso de Aguilar y viuda del secretario real don Bartolomé Sánchez de Badajoz (1479.12.08, AHPCO, PNCO, 14119P, 2, fol. 1r.). En ese momento las tenía Cristóbal de Lasa en representación de dicha mujer, que lindaban con las casas de Juan Muñoz de Gálvez, por un extremo, y por el otro con las de Bartolomé Ruiz de Gálvez (1479.08.16, AGA, Sección Priego, leg. 1107-10, fols. 623r-670v.). También en 1492 vuelve a aparecer don Gómez de Figueroa, alcaide de Antequera, con sus propiedades vinculadas al mayorazgo, en esta ocasión con casas en la villa de Santaella adyacentes con las de Pedro Fernández de Buenrostro y con casas de Alonso del Postigo, con el adarve y con las calles. Además, añaden otras casas que cuentan con un establo y corral y una casa-solar (1498.10.02, ADPCO, caj. 1 , n. 32, s.f.). Más evidente es la noticia del año 1500, momento en el que Juan de Godoy, que aún seguía siendo alcaide del castillo, indica al corregidor de Córdoba, que encuentre a los culpables del robo de la piedra, ladrillo y madera de la fortaleza de Santaella (1500.08.31, AGS, RGS, fol. 355r.).

\section{D) Primera mitad del siglo XVI}

Sin duda, el castillo estaba medio derruido para estas fechas, hecho confirmado en 1523. En esta ocasión, don Pedro de los Ríos, veinticuatro de la ciudad de Córdoba, pide a Carlos V que se le haga merced de la tenencia del dicho castillo, indicando que allí: "no avía ninguna fortaleza porque estabda toda cayda, salvo vna torre, porque el señor rey don Enrique, vuestro bisabuelo, de gloriosa memoria, mandó derribar la dicha fortaleza por los robos e fuerças que della le fazian e porque los cavalleros comarcanos la vsurpavan muchas veces, non enbargante, que el reyno de Granada estaua por ganar para cuyo efecto se fizo la dicha fortaleza e se tuvo por menor ynconviente el peligro de los moros que las vexaçiones e dapnos que hazian los que la vsurpavan desde ella, a que no ha avido en ella alcayde ni los católicos reyes de gloriosa memoria, nuestro señores, padres e aguelos, permitieron que se tornase a refedificar nada en la dicha fortaleza por los ynconvynyentes suso dichos (...)"(1523.07.26, AGS, CCA, Leg. 159, doc. 48-1, fol. 1r.).

De hecho, más adelante, se especifica en el mismo documento que "no avia ninguna fortaleza salvo vna torre con un lienço de adarue quel conde de Cabra hizo quando tomó esta villa a don Alonso de Aguilar (...)". Esta reforma es fruto del enfrentamiento en la captura del Gran Capitán, que posteriormente produjo que el Conde de Cabra se apropiara del castillo y lo reforzara defensivamente. Esto coincide plenamente con la real cédula del 8 de febrero de 1478, en la que se solicitaba la tasación de las obras hechas en el castillo de Santaella por el mariscal para su posterior abono (ANDRÉS, 1951: 643). En realidad, para el siglo XVI la fortaleza se destinaba más a una función honorífica que un sentido estrictamente militar. Existe un escrito de 1523 que explica el intento de don Pedro de los Ríos de apropiarse del castillo con esa finalidad:

"(...) vino el dicho Pedro de los Ríos, viernes catorce de noviembre a la media noche y entró en la dicha torre y fortaleza syn que nadie del pueblo lo viese y tomó la posesysyon della, dize que por virtud de una çédula de merçed que vuestra magestad le hizo de la que él nos presentó vn traslado, bien creemos que la dicha çédula fue engañada (...) porque es notorio que de reedificarse la dicha fortaleza y aver alli de en ella vuestra magestad, no ay de que sea servido antes de servido, y nosotros sus vasallos destruidos y desypados a la menor rebocaçion que en el reyno aya, por que está claro que las fortalezas desta cibdad no estando en frontera de reynos estraños, no se quieren para 
otro fin, vylmente suplicamos a vuestra magestad nos manda confirmar la cedula de merced que nos tiene hecha derogarla que al dicho pedro de los ríos hizo, y por evitar la ocasión que a vuestra magestad le dan y por tomandole por la dicha tenencia y fortaleza y porque no tengan codiçia della vuestra magestad nos ha por merçed de darnos liçençia que derrybemos la dicha torre y lienço de adarve porque con quitarse esto la dicha villa quedara libre para que ninguna persona ni caballero de los comarcanos se pueda hazer fuerte en ella en lo qual vuestra magestad nos hará señaladamente merced (...)" (1523.07.26, AGS, CCA, leg. 159, doc. 48-2, fol. 1r).

Lo cierto es que el emperador decide en junio de 1524, que se derribase la fortaleza y torre de la villa de Santaella junto a sus adarves, para que en su suelo pudiesen los vecinos edificar casas y así aumentar la población (1524.06.25, AHPCO, Sección clero, Lib. 6532, Tumbo del Monasterio de San Jerónimo, núm. 36, leg. 8, Memoria de la señora doña Teresa de Hoces, fols. 187r-190r.). Esto resultó todo un éxito, pues trece años después en las fuentes documentales aparecen vecinos que obtuvieron solares. Por ejemplo, Martín Ruiz Bermejo, obtiene un "solar con su bóveda de la torre nueva, que salía a la plaza, con todo el solar de ella" que, además, "iba a dar del campo por donde se entraba a la villa" (1537.01.20, AHPCO, Sección clero, Libro 6532, Tumbo del Monasterio de San Jerónimo, fols. 180r-182r.). Está claro que la torre citada en esta referencia, es la que existe hoy día y que ha sido intervenida arqueológicamente. De igual manera, aparecen unos datos muy importantes del entorno que se está tratando, concretamente desde el propio torreón hasta la puerta de entrada al castillo, llamada hoy día "la puerta de los caídos". Una noticia de 1572, manifiesta la existencia de viviendas según se plasma en el documento al mencionar "unas casas, que dizen del castillo, junto a la plaza de dicha villa de Santa Ella, otras casas en dicha villa, cerca de la puerta de ella, linde con el adarve" (Ibidem, fols. 174r-176v.). Por tanto, ya se estaba reutilizando la muralla para que los vecinos instalasen sus residencias. Una muestra más de la decadencia del castillo. Y dicha situación continuará empeorando durante los siglos siguientes ya que seguirán mermándose los lienzos de muralla y deteriorándose los vestigios de las torres del cinturón defensivo, quedando mejor conservada la que ha sido intervenida en este estudio.

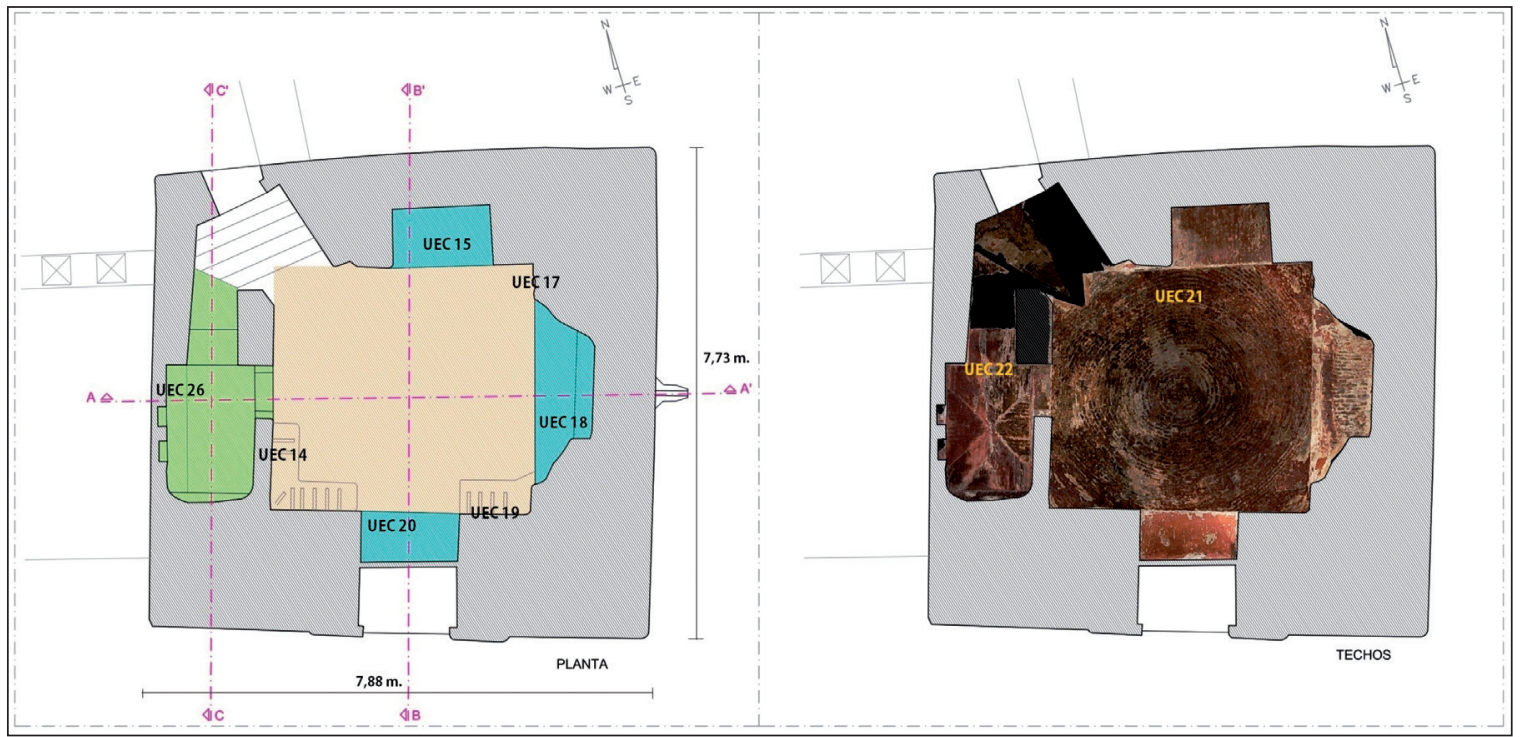

Fig. 7. Planta y cubiertas de la cámara principal de la torre analizada con sus medidas correspondientes. (Elaboración propia de los autores). 


\section{REGISTRO ARQUEOLÓGICO ${ }^{4}$}

El resultado de la documentación arqueológica realizada en la cámara principal de la torre de Santaella en 2015 supuso la supervisión de las unidades de carácter arqueológico susceptibles de ser afectadas por futuras obras de puesta en valor y el estudio de los principales paramentos internos de la torre. En este sentido, el propósito concreto de la intervención arqueológica fue la de evaluar el estado del conjunto de estructuras y depósitos arqueológicos con el fin de dar una interpretación a la secuencia estratigráfica y su evolución históri$\mathrm{ca}^{5}$. Se hizo un diagnóstico del estado de conservación de las estructuras documentadas tanto de apoyos como de alzados. Igualmente se estudió de manera previa el espacio a intervenir (según proyecto), analizando su localización y el estado de preservación de los muros conservados en el inmueble, con el fin de elaborar y proponer las ulteriores medidas de mantenimiento, concitando la documentación del hito patrimonial con la futura valorización para la sociedad.

\subsection{Los periodos constructivos documentados y adscripción cronológica}

\subsubsection{El origen de la torre sureste}

Será durante los convulsos años del siglo XII con la llegada de los almohades cuando se gestaría en Santaella todo un proceso edilicio en el entorno del castillo. Se eleva en este momento de "eclosión constructiva almohade" (MÁRQUEZ, 2018: 11), junto a toda una serie de transformaciones defensivas en la Campiña cordobesa y en las márgenes del Guadalquivir, la torre sureste de la fortaleza santaellense. como se puede observar todavía en la actua- lidad, se trata de una torre de flanqueo de tapial, de planta cuadrada, realizada sobre una doble zarpa de cantería. Sobre este bloque pétreo, se desarrollan y disponen distintos hilos de fábrica encofrada que conforman un núcleo muy hormigonado sobre el que descansan los muros de cierre de la cámara principal. La presencia de una torre maciza ya fue adelantada en su día por Alberto León, cuando hizo una aproximación a la misma:

"El interior de la torre presenta un aspecto lamentable. No sabemos cuál fue la distribución interior; en principio por los acusados cambios de cota entre el exterior y el interior de la fortaleza, la existencia de un potente zócalo y la ausencia de aspilleras de iluminación, es lógico pensar que la torre fue desde el principio una construcción maciza, al menos en sus dos pisos inferiores. No creemos que pudiera contar con aljibe interior pues la apertura a la altura del suelo de la Plaza de un profundo hueco en su lado sur, permite hacernos la idea de un sólido y macizo basamento interior sobre el que se alzaban las estancias superiores" (LEÓN, 2003: 10).

De la lectura de los paramentos tanto exteriores como interiores, podemos adelantar que la UEC 01 se corresponde con el alzado sur del basamento o zarpa pétrea inferior de la torre objeto de estudio. Se pudieron identificar numerosas transformaciones producto de las diferentes reformas, erosiones y usos realizados fundamentalmente en el siglo XX. Mediante la observación directa de las fábricas y la comparación con las fotografías de época, es fácil comprobar las diferentes afecciones que su parte inferior sobrellevó. Como se puede apreciar en la figura 8, este basamento aparece roto en gran parte de su extensión para la colocación de un quiosco y con posterioridad una vivienda, ambos anteriores a los años 70 del siglo pasado. A causa de la colocación de estos añadidos, se horadó el zócalo original de sille-

\footnotetext{
4. Los datos de la intervención que exponemos, se recogieron durante el año 2015 (RODERO, 2015) en el interior de la cámara de la torre de Santaella (figs. 6, 7 y 18). Con posterioridad en el año 2018 se realizaron intervenciones sobre el exterior y los alzados de la torre (LÓPEZ GARCÍA, 2018) y en el interior del Patio de Armas (BASCÓN, 2018b) cuyos datos consultados de las Memorias Preliminares inéditas depositadas en la Delegación Provincial de Cultura en Córdoba mencionamos en este artículo.

5. Para documentación de los cuerpos de fábrica se ha procedido al estudio y levantamiento fotogramétrico singular de los alzados de detalle adaptando la metodología de las unidades estratigráficas constructivas (UEC) según el trabajo de 2003 de Camilla Mileto y Fernando Vegas para el Santuario de San Juan de la Penyagolosa (Castellón) y la iglesia de San Juan de los Reyes en Granada (MILETO y VEGAS, 2003a y MILETO y VEGAS, 2003b).
} 


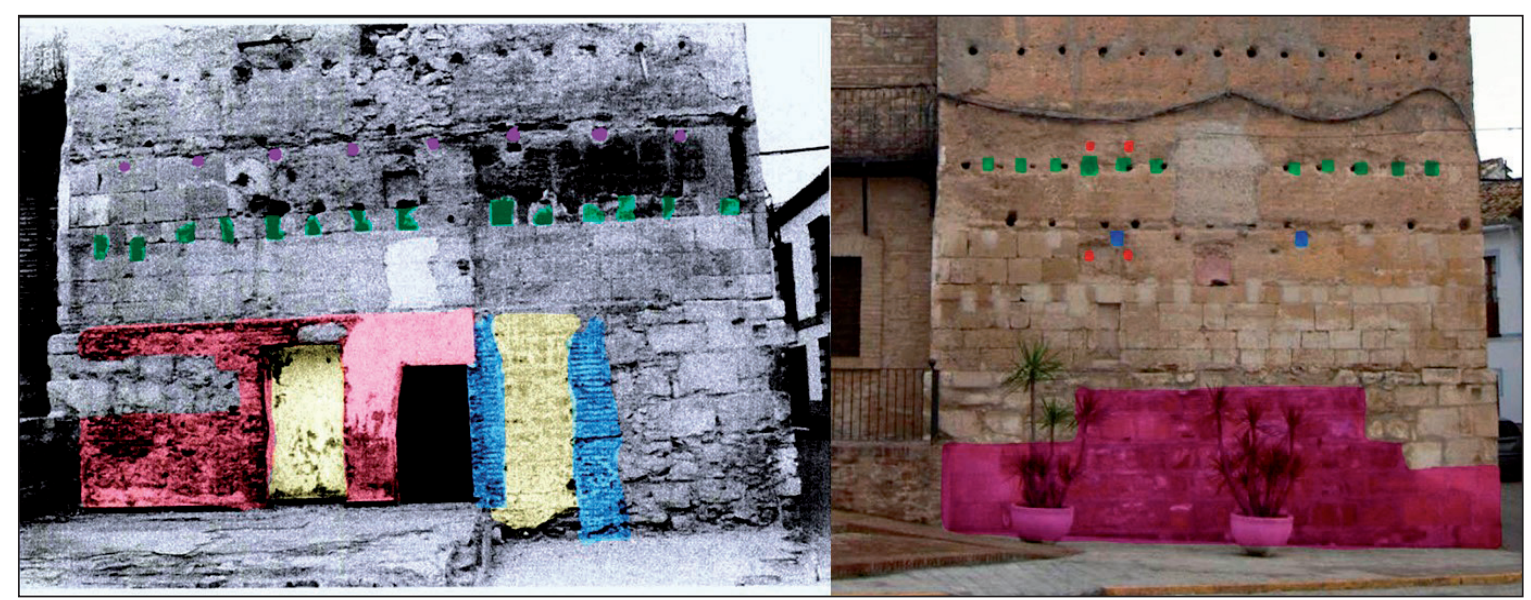

Fig. 8. A la izquierda, diferentes afecciones contemporáneas sobre el basamento pétreo de la torre, realizadas por las viviendas adosadas del siglo XX. Vanos, cerchas y cubiertas se representan en diversos colores. A la derecha, en color rosa, sillería de restauración del año 2000. (Montaje propio de los autores sobre fotografías contenidas en LÓPEZ GARCÍA, 2018).

ría, abriéndose al menos tres huecos. La apertura y cegamiento de estos vanos afectó a esta parte original de la torre que conservó soltando piezas de cantería en las esquinas SE y SO. En la esquina SE, se conservaban 7 hiladas de sillares, de las que las tres inferiores se encontraban muy deterioradas y fueron sustituidas durante la restauración de principios del s. XXI. Quedaron las 4 siguientes definidas por tres hiladas de sillares de grandes dimensiones colocados a soga y trabados con mortero de cal bastardo, mientras la hilada superior, definida por sillarejos rectangulares, marcaban la línea de imposta de la segunda zarpa. En la esquina SO nos topamos con un desarrollo similar, es decir, 7 hiladas de cantería muy deterioradas conservándose en buen estado solo las tres superiores. Estas se definen por dos líneas de sillares de grandes dimensiones y sillarejos careados con forma rectangular en la hilada superior. El resto del zócalo se encontraba roto o muy erosionado.

La UEC 03 describe el segundo cuerpo de cantería de la cara Sur. Sobre el primer prisma de piedra (UEC 01) arranca una serie de sillarejos perfectamente escuadrados, sujetos con una llaga de mortero, que refuerzan las esquinas y encadenan las cajas de tapial inferiores de la torre. Se distribuyen en un muro corrido de 4 hiladas, las dos inferiores presentan un módulo similar, alargado y rectangular, mientras que la tercera se caracteriza por un mayor desarrollo de las piezas, forma cuadrada y rotunda. Sobre la última tongada de sillarejos prismáticos, apoyará el bloque de tapial. Esta cuarta hilada aparece rota en todo su horizontal por una serie de huecos de forma cuadrada, resultado de la colocación de vigas rectangulares del forjado de la vivienda de los años 70 del siglo pasado. En las esquinas SE y SO remontan dos líneas de sillares que robustecen las esquinas y encadenan las primeras tapias. En ellas, se conservan la alineación de los orificios de las tirantas de la cubierta de la vivienda antedicha que se adosaba a la torre. Sobre estas y rompiendo el tapial se localizan los huecos de los pares de la cubierta a un agua de la casa contemporánea.

En la intervención recientemente realizada en 2018 se menciona la posibilidad de que las hiladas superiores de la base de la torre que encadenan las tapias se correspondan con la fase fundacional de la torre en época medieval cristiana "facies edilicia n ${ }^{\circ}$ 1" (LÓPEZ GARCíA, 2018: 33, figs. 13 y 14). A este respecto y en otro punto de la memoria, se expone que su adscripción histórica probablemente sea de época "tardoalmohade-mudéjar" (LÓPEZ GARCÍA, 2018: 32), lo que denota la complicación de matizar su origen. Igualmente se constata la 
presencia de dos canteras diferentes en los sillares y sillarejos: piedra ostionera y calcoarenita (LÓPEZ GARCÍA, 2018: 37, fig. 19).

En este sentido, se ha pasado por alto que el tipo más claro de calcoarenita, se utilizó también como piedra de restauración de la obra de 2002, para restituir las roturas de la pérdida pétrea ocasionada por diferentes acciones tectónicas, como la colocación de las vigas del forjado de la vivienda de los años 70. Para las obras de reforma y restauración de las roturas de las casas contemporáneas, se emplearon varios tamaños de sillares, sillarejos e incluso ladrillos macizos en hiladas en el arranque de las tapias. Esto dificulta la adscripción cultural de la construcción del basamento y no puede datarse para un periodo específico basándose únicamente en una lectura paramental. La realización de una calicata en el actual nivel de suelo de la Plaza, a los pies de la torre, permitirá resolver dos incógnitas fundamentales. Por un lado, la fecha de construcción, y por otro, hallar el nivel de cimentación o de alzado, puesto que ninguna de estas dudas se ha podido resolver definitivamente hasta el momento.

La UEC 02 define las hiladas inferiores de la cara este del basamento inferior de la torre. Este cuerpo se presenta con unas características similares a las de su fachada sur (EC 01). Aunque muy restaurado por las acciones de primeros del siglo XXI, existe una variedad importante de técnicas constructivas, agravado por la ausencia de imágenes históricas de esta unidad constructiva donde pudiera apreciarse con claridad la fábrica anterior a las reparaciones realizadas. De la observación in situ podemos concretar que solo las esquinas sury norte que conservan piezas originales, consistentes en sillares de gran tamaño trabados con mortero de cal y arena. En las imágenes de los años 70 y 80 del siglo $X X^{6}$, se aprecia que gran parte de esta fachada se encontraba enlucida con mortero hasta al menos $1,5 \mathrm{~m}$. de altura, restando del basamento original las dos hiladas superiores de sillarejos de calcarenita. La esquina sur con 7 hiladas superpuestas de si- llares y sillarejos conserva de la fábrica original 4 tandas de la hilada superior que consisten en dos de sillares y dos de sillarejos rectangulares.

El paramento central y la esquina norte de la UEC 02 se restauraron con la tradicional alternancia de ladrillos macizos y mampostería careada que enmascara y recubre la fábrica original del asiento de la torre. Sobre las dos hiladas superiores de la zarpa pétrea UEC 02 se desarrolla en alzado la UEC 04, caracterizada por la presencia de 4 hiladas de cantería colocados a soga. Sobre esta descansan dos hiladas más de sillares en las esquinas y cajas de tapial en el centro. Estas cajas de tapia arrancan desde una hilada de ladrillos macizos en la cara sury en la cara este.

Por lo que respecta a las caras oeste y norte de la zarpa de la torre sureste de Hornachuelos, se repite el mismo esquema constructivo, aunque para el caso del lado norte, no podemos aportar ningún dato nuevo ya que actualmente la base está tapada por la adhesión de una vivienda. Por su parte la cara oeste, presenta el adosado del antiguo Juzgado que impide realizar un análisis directo de su masa, aunque por lo que se aprecia en la esquina SO se repite el mismo ritmo edilicio.

El muro UEC 05 que se desarrolla en la cara sur de la torre, apoya sobre la UEC 03 caracterizándose por estar constituido por 7 tongadas de obra encofrada sólida. En origen sobre este paralelepípedo, se elevaba la UEC 08 que presentaba un vano hacia meridión posteriormente sustituido por una ventana renacentista. Nos encontramos con un muro (UEC 05) de tapial macizo hasta la hilada 7, a partir de este punto se eleva la UEC 08, realizada en tapia, pero de menor anchura, que limita la cámara de la torre por el sur. De la observación de la superficie de las tapias se aprecia, que la mitad de la fachada sur se reparó con una gruesa capa de cemento y rasillas que impedían analizar las características y disposición de las cajas de tapia. La parte inferior de esta fachada, desde la hilada 1 hasta la 6, se encontraba en

6. Colección de imágenes, propiedad de Francisco Palma Franquelo, y cedidas por el Excmo. Ayuntamiento de Santaella. 
relativo buen estado original, mientras las hiladas 7 a 14 presentaban múltiples "soluciones y materiales añadidos en la década de 1970, que le daban inicialmente a la torre ese aspecto gris homogéneo y aparentemente sin faltas serias en la fábrica" (LÓPEZ GARCÍA, 2018: 43). Observando la figura 3 podemos vislumbrar en la hilada 6 la colocación de las cajas de tapia en la cara sur de la torre. Se dispusieron 4 tapiales en longitud donde se aprecian las rebabas de los tapiales, indicios de un posible encofrado masivo. Asimismo, refleja las huellas de 6 tablones horizontales que estarían unidos a unos listones verticales mediante clavos metálicos según el esquema de ese momento (MÁRQUEZ, 2018: 7). Se conforman unas cajas con "un tapial muy duro y bien compactado, con cajones que abarcaban el diámetro total de la torre y de unos $80 \mathrm{~cm}$ de altura, con las marcas de las tongadas superpuestas del prensado del tapial de unos 10-15 cm. de espesor promedio cada una" (LÓPEZ GARCÍA, 2018: 34). El interior de las cajas de tapia conserva, en algunos casos, el material de las agujas de los mismos (LÓPEZ GARCÍA, 2018: 36, fig. 18).

El alzado de tapial este (UEC 06), que apoya en UEC 04, conservaba al menos las 6 hiladas inferiores en mejor estado, probablemente por la acción del parcelario que amortiguaba la erosión de las cajas superiores. En este lienzo podemos comprobar cómo, a partir de la hilada 7, se desarrolla en altura el muro UEC 09 que delimita la cámara por su lado de levante.

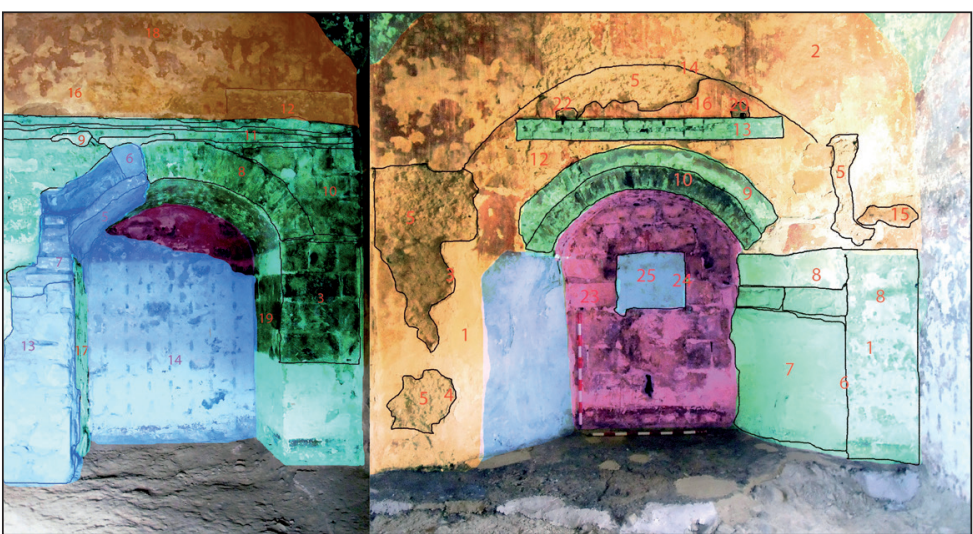

Fig. 9. Fases constructivas documentadas al interior de la torre, en Ios muros UEC 15 y 18. En naranja: fase almohade; en verde: fase bajomedieval; en burdeos: etapa moderna y en azul: periodo contemporáneo. (Elaboración propia de los autores).
Esta fachada oriental arrancaba de una hilada de tapial encadenada entre sillares pétreos. La anchura es menory tiene una disposición horizontal de dos tapiales centrales, y en las esquinas, el ancho de los tapiales de las caras perpendiculares se conforma de una disposición análoga a varias sogas en el centro y tizones en las esquinas. En ella, apenas se aprecian las rebabas de las cajas de tapial y la huella de la tablazón (tapia) para el encofrado que estarían entre las hiladas 5 y 6 . Las hiladas inferiores y la zarpa de mampostería, no se encuentran a la vista por la presencia de la vivienda actualmente adosada.

Sobre este bloque pétreo de tapial, se eleva un muro UEC 09, definido por 7 hiladas de tapial que apoyan sobre la UEC 06 hasta la azotea de ladrillo y constituye el cerramiento norte de la cámara principal de la torre. De menor grosor, como es habitual en este tipo de construcciones, presentaba un vano hacia levante que, posteriormente, será transformado en dos fases consecutivas: bajomedieval cristiana y moderna. La fachada oeste UEC 07 del bloque de tapial de la torre, está hecho por 7 hiladas que apoyan en la zarpa de cantería, distribuidas horizontalmente con el ancho de una caja en la esquina y dos cajas longitudinales en el centro. El ancho de la última caja, forma la cortina sur del castillo. Se hallaba cubierto por cemento y muy restaurado, lo que enmascaraba las huellas de la tablazón de la tapia. Sobre este muro arrancaría el cierre occidental de la cámara de la torre UEC 10. La UEC 20 determina el cerramiento de la cámara por su lado oeste y apoya sobre parte del macizo de la torre de tapial UEC 07. Este paramento fue cortado y sustituido en parte por una refectio realizada en época bajomedieval cristiana cuando se instaló una pequeña antesala abovedada al interior (ver fig. 4).

La UEC 11 define el bloque macizo de tapial que apoyaba sobre el basamento, se le ado- 


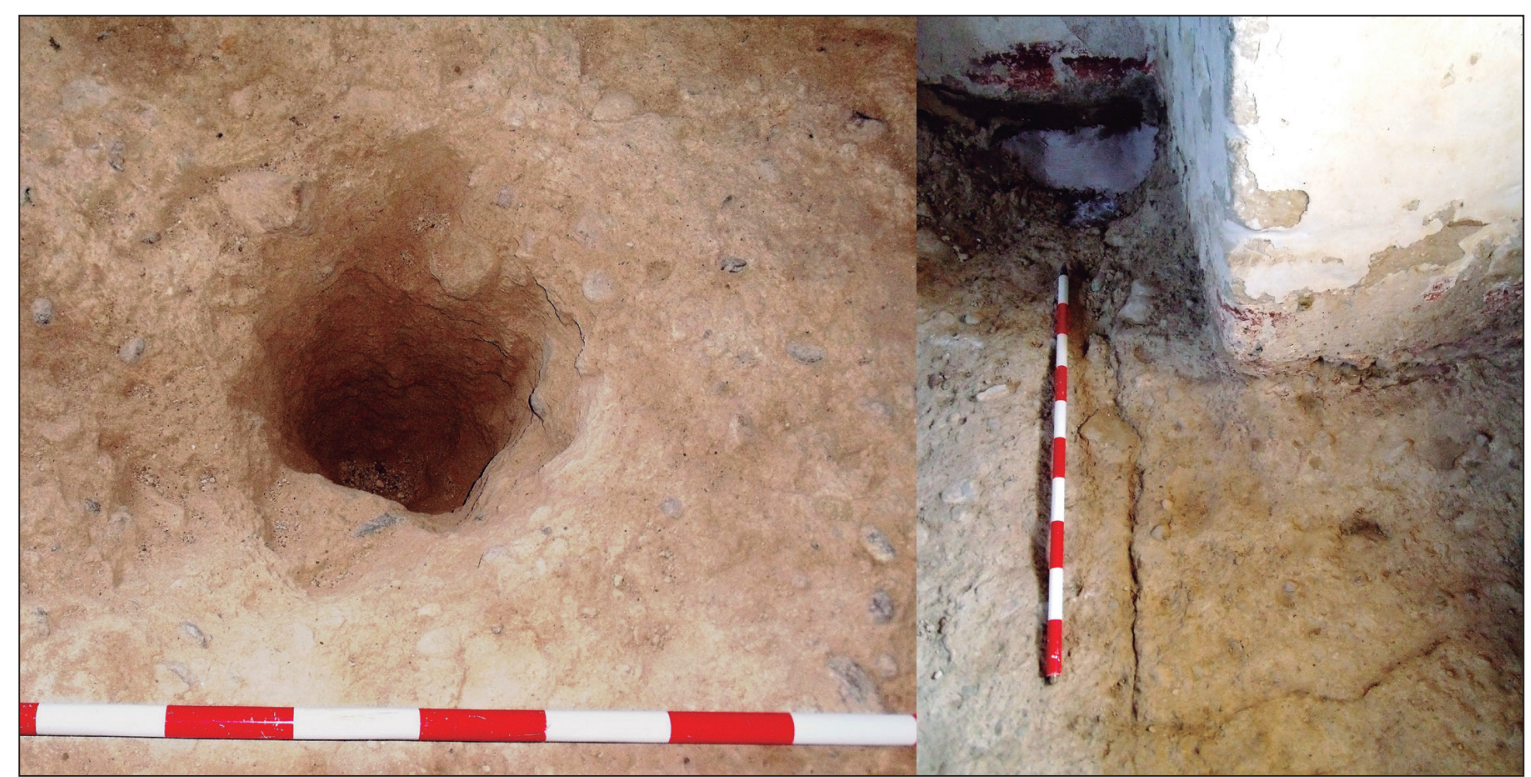

Fig. 10. A la izquierda detalle de uno de los postes de arriostrado de las cajas de tapial. En la derecha el contacto entre hilos de cajas de tapial en el suelo de la cámara. (RODERO, 2015).

sa la cortina este del castillo y sirvió de apoyo al muro UEC 12, donde se encontraba el acceso principal a la cámara. Por lo que respecta al alzado norte UEC 12, durante la intervención realizada por José Miguel Bascón, se comprobó que parte de la unión de la torre con los lienzos de la muralla sury este, se encontraban rotos tanto por la fachada norte como por la oeste (BASCÓN, 2018b: 179-181). En nuestra opinión, la ruptura de parte de las cortinas amuralladas tanto este como sur responde a las transformaciones llevadas a cabo en época bajomedieval cristiana en la cámara principal. Estos cambios de la cámara suponen la quiebra de parte de los muros de tapial de la torre por los lados oeste y norte; y el corte de las cortinas este y sur de la muralla original de tapial del castillo, dado que era la única manera de poder transformar el vano de la cara norte desde el patio de armas (BASCÓN, 2018b: 179). Aun así, se conservaron hiladas de tapial original de la UEC 12 por encima de la reforma de cantería de la ventana septentrional.

En cuanto al acceso al interior de la cámara por la esquina NO desde el paso de ronda, se conserva el hueco y parte de las jambas originales que se documentaron en la intervención de 2015 (RODERO, 2015: 24 y ss.). En esta intervención dentro de la cámara se efectuaron 7 pequeños sondeos donde se comprobó la evolución constructiva de la torre por medio de la observación de los paramentos internos de las UEC 08, 09, 10 y 12 (ver figs. 3, 4 y 9). Además, se apreció al mismo tiempo la parte de la cimera de las cajas de tapial que constituyen el bloque macizo de la torre (UEC 05, 06, 07, 11) transformado en suelo de la cámara. El resultado de las intervenciones realizadas, una en 2015 y dos en 2018, nos acerca a la evolución diacrónica de la torre y a su posible adscripción cronológica.

Exteriormente nos encontramos en esta primera etapa edilicia y, por tanto, fundacional con una torre cuadrada, de fábrica mixta, que se eleva hasta las 14 hiladas de tapial sobre una doble zarpa de cantería. Alcanza la cota de 245,45 m.s.n.m. la facies superior del bloque prismático, formado por cajas de tapial de 7 hiladas sobre la que se apoyan los cuatro muros perimetrales de la cámara principal. Estos muros de tapial desarrollaron en altura otras 7 hiladas hasta llegar a la cubierta plana.

La cota de arranque de los muros perime- 
trales de tapial de la cámara se corresponde con la superficie de las últimas cajas del bloque prismático, que a su vez forman el nivel de suelo de época tardoislámica y bajomedieval. Sobre la superficie de este bloque prismático, se levantan las cuatro paredes de la habitación con un grosor menor (MÁRQUEZ, 2018: 5). Esta disminución del grosor permite que los muros apoyen directamente sobre las cajas de tapial inferiores usándolas como solera. Se evitaba así que las caras interiores de los muros de la estancia, coincidiesen en vertical con las exteriores de la caja del basamento. Si existiera una alineación de este contacto conllevaría a la fragilidad de la construcción.

En la planta de la cámara, parte cimera de los bloques de tapial (UEC 05, 06 y 07), se documentaron un par de huecos que se correspondían posiblemente con postes de arriostrado de las cajas de tapial, posteriormente reutilizados (ver fig. 10). Igualmente pudimos apreciar en esta superficie el contacto entre hilos (ver fig. 10). La técnica de construcción sigue la evolución habitual que los alarifes almohades utilizaron para este tipo de edificación defensiva: "Paso 1. Preparación del cajón de encofrado (tapial) inferior; Paso 2. Vertido de tongada de cal; Paso 3. Sucesivas operaciones, por tongadas, de vertido de espuertas de argamasa y consiguiente apisonado; Paso 4. Desencofrado del tapial tras el fraguado de la argamasa; Paso 5. Rebaje del cajeado para mechinal del tapial superior; Paso 6. Preparación del cajón de enco- frado (tapial) superior (como inicio del proceso)" (GRACIANI, 2008-2009: 19). Dado su nivel de deterioro exterior, en el interior de la cámara, solo pudimos apreciar la existencia de cajas de tapial calicastrado (GAZTELU, 1899: 76) cuya argamasa presentaba color blanquecino con alta presencia de cal y arena en su interior. Asimismo, encastrados se apreciaban ripios, que formaban parte de la fábrica original (LÓPEZ GARCÍA, 2018: 34, fig. 16).

La presencia de un suelo de ocupación original al interior de la cámara, se detectó por los vestigios de un hogar y por la constatación de testigos de una banda pintada en almagre en derredor del perímetro de la estancia. Esta banda está presente en diferentes puntos, a modo de rodapié y marco de tapiz del suelo. Está junto al vano de entrada y bajo los vanos norte y sur. Respecto al hogar, se trata de una pequeña fosa excavada en el núcleo de tapial de la torre, quizás aprovechando el orificio de algún maderamen y que fue utilizado en época tardoislámica como fogón o lumbre (ver fig. 11). El muro de tapial que cierra la estancia por su lado este, cara interior de la UEC 09, permitió definir como componente principal una tapia mejorada con cal. Presentaba un color grisáceo tirando a blanquecino, cal y ceniza que permitió mejorar la durabilidad y el comportamiento ante el deterioro. La calidad de la fábrica interna, en este caso es de tapia acerada, es decir "...) de tierra con mezcla de cal arrimada y repelada al tablero o tapial” (REJÓN DE SIL-

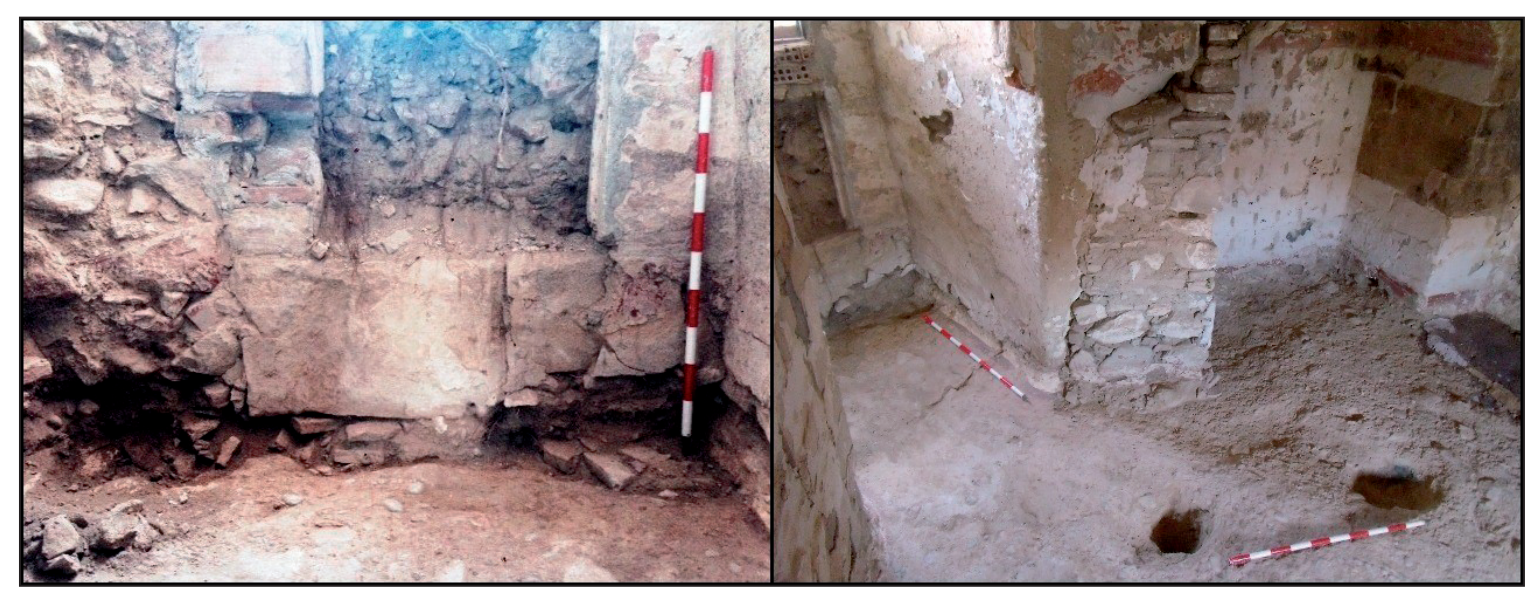

Fig. 11. Detalle de la evolución estratigráfica de la puerta desde el suelo original: derrumbe, umbral de piedra y colmatación del vano (izda.). Vista cenital de las huellas de hogar y pilar sobre el suelo de tapial de la cámara (dcha.). (RODERO, 2015). 
VA, 1788: 7). Una tipología para la construcción defensiva que normalmente se vincula a la cronología tardoislámica: "Ha de considerarse que el carácter acerado o real de un tapial es propio de obras que, funcional o mecánicamente, lo exigen; así, para el caso sevillano, aunque las primeras fábricas mejoradas son pre-almohades, la cal en mayores proporciones se incentivó en la construcción militar e hidráulica almohade (...)" (GRACIANI, 2009: 123). El muro interno este UEC 09 cuenta con unas dimensiones en anchura menores que la tapia sobre el que se apoya, actuando esta última como asiento. El vano en origen, presentaría los muros abocinados hacia una o dos saeteras, aun cuando no quedan vestigios o huellas de ellas, es notorio que estas soluciones eran un tanto arcaicas para las fortalezas almohades del sur peninsular (MÁRQUEZ, 2018: 18).

El muro de cierre sur UEC 08 de la estancia se encontraba en un estado considerablemente bueno. Hacia el interior, al igual que el muro norte (UEC 12), está construido repitiendo el mismo esquema tectónico, es decir, paño de tapial de calicanto que presentaría en su eje un vano, posteriormente reformado en una ventana de sillería, ladrillo al interior y arco horizontal de dovelas al exterior.

La construcción de la torre se realiza siguiendo el procedimiento de encofrados ligneos que formaría un maderamen en cuadrilátero como el definido por Samuel Márquez (MÁRQUEZ, 2018: 11). En nuestro caso, apenas se observan rebabas de tapiales, no pudiendo confirmar la existencia de agujas pareadas junto a estas que certifiquen un encofrado continuo, por nivel o hilada, como en el caso de El Vacar (CÓRDOBA, 2004: 124).

Del análisis visual de las cajas de tapial se puede concretar que la fijación y compactación del material (GIL y MALDONADO, 2015: 5), se hizo mediante pisón o prensado del tapial fraguando posteriormente (LÓPEZ GARCÍA, 2018: 34). Se conoce que la función constructiva de la fábrica era la de levantar los muros principales. Esto se realizó mediante un encofrado de cajones continuos con tapiales teste- ros. Los muros perimetrales de la cámara tienen un ancho aproximado de 1,81 m. de media y se apoyan sobre los inferiores que actúan a modo de solera. La anchura determinada en estos inferiores alcanzaría los 2,10 m. Para el contacto entre bancadas o hilos se ha optado por la solución más simple, la superposición directa de los cajones, como se aprecia en un roto existente en el muro este. El contacto entre cajones es a juntas encontradas, mientras que la junta común es en ángulo recto (GRACIANI, 2009: 121). La longitud de las cajas de tapial oscilaba entre los 1,72-74 y 1,81 m. y unos $0,80 \mathrm{~m}$. de altura, dentro de las medidas y técnica propugnada para este tipo de fábrica por Ibn Jaldún en el siglo XIV: "las paredes son sola arcilla. Se sirve para esta operación de dos tablas, cuya longitud y anchura varían según los usos locales; pero sus dimensiones son, en general, de cuatro varas |codos| por dos. Se vierte allí (en el encofrado) una mezcla de tierra y cal que se apisona enseguida con pisones hechos a propósito para este fin" (GURRIARÁN y SÁEZ, 2002: 562). En planta no ha sido posible establecer bien las medidas de los cajones del macizo de la torre, pues se ha perdido la huella de las agujas y puntales utilizadas en su construcción. La historiografía sobre este tipo de cerca, en época almohade, muestra el carácter variable de la anchura de las murallas y torres, determinadas por la altura y necesidades defensivas de sus constructores (LEÓN et alii, 2004: 254). No obstante, la técnica constructiva es la misma para la torre SE del castillo y las torres del Barrio Bajo de la cerca de Santaella, mientras que varía en composición respecto a la localizada en la calle Concepción de esta localidad (GARRIDO, 2017). Ejemplos de diferentes medidas de las cercas almohades las encontramos en Jaén y en Córdoba: "hisn de Castro Ferral (Jaén) con una anchura de 1,65 m, la muralla de Andújar de 1,50 m de grosor, el mismo castillo cordobés de El Vacar cuyos muros alcanzan 1,70 m de anchura, con una altura de los cajones de 84 cm" (ESLAVA, 1989: 54). Las dimensiones de la torre, muestran una planta cuadrada con unas medidas parecidas: muro sur 7,47 m. el este 7,35 m, el norte 7,66 m. y el oeste 6,75 m. aprox. (ver figs. 7 y 12). El uso de torres cuadradas o de planta 
regular es recurrente en la arquitectura andalusí, como en Baños de la Encina. Incluso, en alguna que otra ocasión, se han documentado torres poligonales o semicirculares desde los siglos X y XI, aunque es algo más excepcional. Algunos ejemplos son la muralla de Talavera de la Reina, la Aljafería o las torres aglabíes de Susa y Sfax, pero realizadas con fábrica de sillería. En el siglo XII la preponderancia de la técnica del tapial en la Península Ibérica y el Norte de África, propia de almorávides y almohades, surgen además de las torres cuadradas, torres poligonales realizadas en dicha técnica de tapia (MÁRQUEZ, 2008 y 2018; PAVÓN, 2012: 11).

Respecto a la cronología de la torre, la falta de material cerámico diagnosticable de su fase constructiva impide una concreta adscripción temporal. Las características constructivas con el basamento doble, la fábrica mixta, las relaciones estratigráficas y los diferentes paralelos existentes para este tipo de edilicia, dan lugar a pensar que la fecha de fundación de la torre fuese dentro del periodo almohade, junto a la posible ampliación del recinto defensivo de la villa de Santaella. La construcción de la torre sureste y de la cerca del castillo documentada al interior del patio de armas (BASCÓN, 2018b: 41) responden a dos criterios fundamentales: la economía de medios y la urgencia en su edificación, como la gran mayoría de las construcciones almohades. El uso de la cantería está presente en la torre en basamento y el zócalo, al objeto de salvar de humedades a las tapias bajas y solventar el nivelado de las mismas. Además, la existencia de este podio contribuía a su fortaleza, ayudaba a la reciedumbre de los muros de tapial, como se ha visto encadenando la primera hilada, desde los cimientos y hasta una altura de no menos de $3 \mathrm{~m}$. sobre el nivel del suelo. De este modo, se alcanza a tener un basamento de formidable resistencia por la sillería y el durísimo tapial empleado. No obstante, cabe mencionar que la tipología de la torre se asemeja bastante al "alto zócalo de dos torres del castillo de Orihuela con recios sillares en las cantoneras o esquinas, con fábrica de tapial de encima de calicanto con mechinales aflorando en superficie, en suma, una de las obras más interesantes de Sharq al-Andalus que podría llevarnos a cronología muy anterior a la propuesta de dominación almorávide-almohade por algunos autores, entre ellos Azuar Ruiz" (PAVÓN, 2012: 9). Construcciones similares las encontramos en Calatrava la Vieja, un torreón de tapial de calicanto con alto zócalo de sillarejo apaisado, reiterado en el castillo de Salvatierra, con tapial de tierra, ambas obras

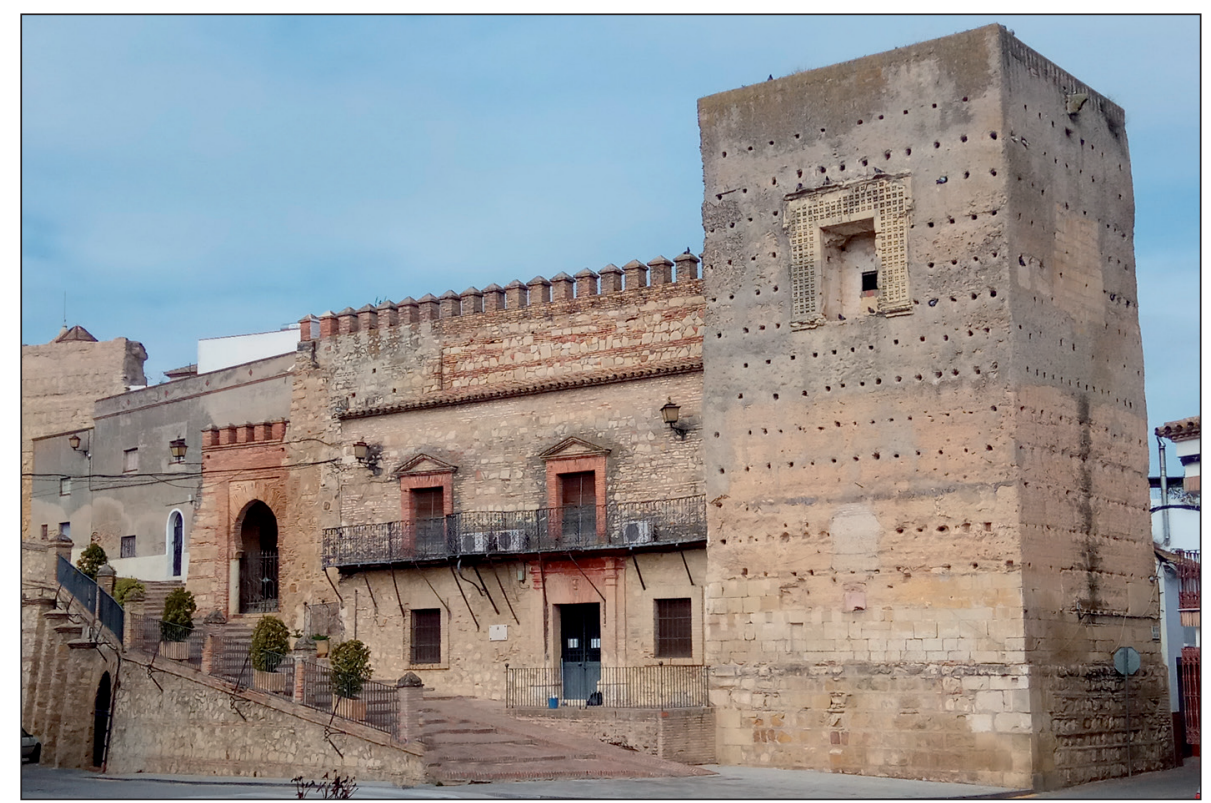

Fig. 12. Torre sureste del castillo de Santaella (Córdoba) previa a la intervención de 2018. (LÓPEZ, 2018a: 285). 
fechables entre los siglos XII y XIII. Igualmente, "(...) en Reina, Carmona, Cáceres, Badajoz, Juromenha, Niebla, Saltés, Gibraleón, Jerez de la Frontera y Palma del Río, por citar algunos ejemplos, se reforzarán las esquinas de algunas torres mediante bloques de mampostería, ladrillos o sillares" (MÁRQUEZ, 2018: 11). Pero el tipo más parecido al de la torre SE de Santaella pudiera ser el de la torre del extremo oriental del recinto de Reina (MÁRQUEZ 2018: 14, fig. 11).

El castillo se encontraría inmerso dentro de esa fortificación de poblaciones que durante el periodo tardoislámico alcanzó numerosos emplazamientos como la torre de la Calahorra, la torre de Belén (LEÓN et alii, 2004: 254) y conjuntos del entorno de Sevilla como Marchena (BELLIDO, 2008: 167), Alcalá de Guadaira, fechada entre 1172 y 1173, el alcázar de Jerez de la Frontera (Cádiz), las murallas de tapial de Cáceres y de la alcazaba de Badajoz (LEÓN et alii, 2004: 254), Andújar, las cercas almohades de Niebla (Huelva), Écija (Sevilla), Palma del Río (Córdoba) y Castillo Anzur (Puente Genil, Córdoba). Las únicas noticias sobre el sur de Córdoba y la Campiña, la suministra el viajero Al-Idrisi cuando viajó por ella en estos años. Parece que existía cierta recuperación hispano-musulmana después de la guerra civil. Menciona la existencia en Iznájar y Alcaudete de sendos castillos de población numerosa y un mercado muy frecuentado. Habla del iqlim de la Campiña donde están Baena, Cabra, Lucena, Monturque, Santaella y Écija, aludiendo a tribus bereberes a las que señala en su emplazamiento, no nombrando en esta zona tribus árabes. Se ve que ya no existe la división administrativa basada en las antiguas Cortes de Taifas o los centros culturales de las ciudades importantes. Solo se habla de las capitales de Sevilla, Granada y Córdoba, centros militares donde residen los gobernadores (ARJONA, 1982b: 122).

Acerca de los primeros momentos de la ocupación durante este periodo, ya hemos mencionado en el contexto histórico, las distancias que existían entre el castillo de Santaella y otros cercanos, o el nombre de dos alcayats islámicos, que confirman la presen- cia de una aljama musulmana. Hay por tanto similitud entre lo plasmado en las secuencias estratigráficas y los escasos datos para esta etapa histórica, sabiendo que las acciones tectónicas más importantes realizadas en la torre debieron de ejecutarse con carácter previo a las transformaciones posteriores.

\subsubsection{La impronta bajomedieval}

En esta fase histórica el registro arqueológico se acerca a una importante reforma producida en el siglo XIV, presumiblemente de manos de uno de los herederos de la Casa de Aguilar, quizás durante el gobierno del titular del señorío, D. Alfonso Fernández de Córdoba. Este esfuerzo no responde a un hecho aislado sino a unas circunstancias histórico-sociales muy complejas. El desarrollo de programas constructivos afecta a numerosos enclaves cuyo máximo exponente en la provincia de Córdoba es la propia capital. La historiografía y los registros arqueológicos muestran la posible construcción del Alcázar viejo de Córdoba en el siglo XIV por Alfonso XI (CASTEJÓN, 196162: 240 y ss). Durante estos momentos y para el caso de Santaella, son significativas las estructuras documentadas en el interior de la torre sureste que definen un importante embellecimiento del interior de la misma. Las principales transformaciones, que afectaron a la torre original almohade, se centran en el interior de la cámara (ver fig. 18) y en las fachadas norte y oeste (ver figs. 13 y 14). En esta fase es cuando se documentan los cambios que afectarán a los muros de tapial UEC 08, 09, 10 y 11, a los 4 vanos y al acceso a la cámara de la torre. Estas mutaciones destacan por el uso de la sillería para jambas y muros y el ladrillo para las ventanas. Dicho momento tectónico de la torre se produce durante la fase bajomedieval cristiana, cuando se pasa de una estancia cuadrada con 4 vanos en eje, dos a dos, a un espacio dividido en dos piezas con bóveda baída y tres ventanas.

El mayor cambio se ocasiona en el muro oeste (UEC10), cuando se rompe parte de la cortina sur que entestaba con la torre por poniente y se demuele dicho muro. Este es susti- 


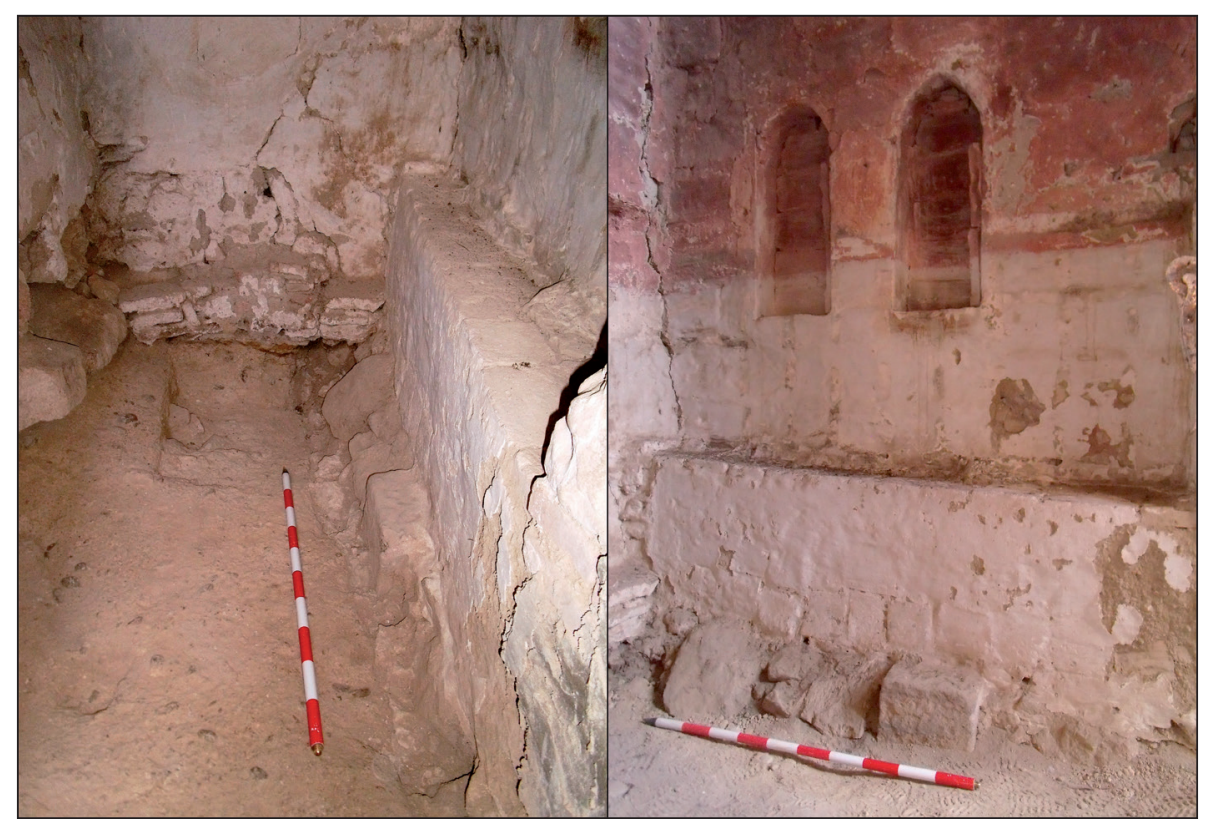

Fig. 13. Relaciones del forro de sillarejos y paramento oeste cortando la tapia tardoislámica (izda.). Forro de sillarejos, rebanco y paramento oeste con doble ventana (dcha.). (RODERO, 2015).

tuido por un paño de sillería (UEC13) formado por la alineación de mampuestos y sillarejos escuadrados, apoyados en el tapial original de la torre por su lado oeste. Debió de tener un vano para iluminar la antesala, aunque actualmente solo se conservan las ventanas geminadas contemporáneas (ver fig. 19). La ruptura del cierre oeste, realizado en origen con cajas de tapial de una anchura de $1.80 \mathrm{~m}$. y su sustitución por este cierre de sillarejos, permitió ampliar la cámara principal con la instalación de un habitáculo hacia poniente de $1.50 \mathrm{~m}$. de ancho.

El nuevo espacio, ganado a costa del espesor del muro oeste (UEC 10), se compartimenta respecto de la cámara original con un tabique de sillarejos (UEC 14) que se adapta en sus extremos a los restos de tapial de la cara interna del muro oeste original. Este tabique se caracteriza por la presencia de un vano, rematado por un dintel recto sobre ménsulas simples, que sirve de tránsito entre la antesala y la estancia principal. El dintel es una pieza monolítica de calcarenita que apoya sobre sendas ménsulas decoradas con una gola o cuarto de bocel que coronan las jambas de la puerta. Sobre él se desarrolla un paño de ladrillo macizo y llagas de mortero de cal bastardo, formado por al menos 6 hiladas que descansa sobre el muro de sillarejos (UEC 14) y soporta la bóveda baída de la torre. Se descubre en la esquina suroeste interior una de las pechinas o arranques de la bóveda de ladrillo (ver fig. 14).

El interior del muro norte (UEC 15) muestra el despiece de las jambas, estribos y riñones de un vano de luz de 1,51 m. Esta ventana se realizó con sillares regulares trabados con una fina capa de cal, soportando un arco rebajado de ladrillo. Los sillares conservaban líneas incisas para el replanteo de las hiladas. Tiene las jambas rectas, sin presencia al interior de un posible abocinamiento, ni estructura defensiva apreciable, tipo tambuco o ventana derramada hacia el interior. Este conjunto pétreo forma la jamba este del vano y actúa como estribo del arco del mismo. Un arco rebajado de ladrillos se dispone en forma curva, salvando el espacio abierto entre los dos pilares de sillares del vano, coronando la abertura o ventanuco norte. Un conjunto de hiladas de mampuestos escuadrados forma el tímpano del arco. Partiendo de este punto, se elevan dos hiladas de ladrillo con sendos tendeles de mortero de cal y arena que se superponen 


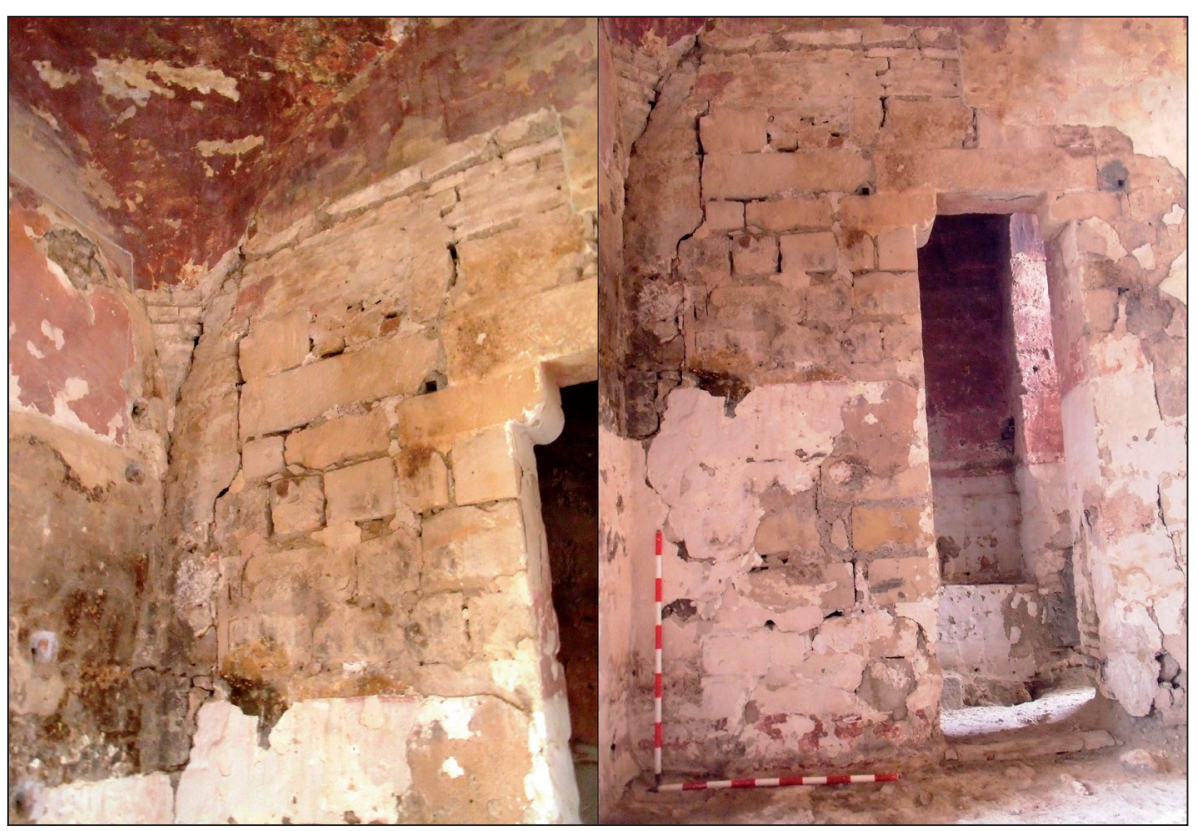

Fig. 14. Muro medianero de sillarejos escuadrados cortando la tapia tardoislámica, rota también por la bóveda baída de ladrillos. (RODERO, 2015).

sobre el arco del vano, determinando un plano horizontal a modo de dintel, rompiendo el tapial del muro norte (UEC 12) que continúa hasta el encuentro con la bóveda de la cámara. Hacia el exterior presenta un cerramiento de sillarejos (UEC 16) de distinto tamaño que conserva una posible saetera de cronología ignota, que fue cegada durante las diferentes obras de restauración (LÓPEZ GARCÍA, 2018: 42, fig. 25) (ver fig. 15). La disposición del forro de sillarejos se realizó rompiendo, por el Patio de Armas, el tapial original de la muralla este del castillo y parte de la fachada norte de la torre, como ya comentamos. En un momento indeterminado del medievo, se realizan en la jamba este de la ventana norte (UEC 15) un conjunto de graffiti incisos. Muestran figuras esquemáticas a modo de haces de líneas que pueden interpretarse como antropomorfas (ver fig. 16). Por la disposición de las líneas de haces, es posible descartar en principio, la posibilidad de su interpretación como pectiniformes, un sistema de cómputo del transcurso de días o de contabilidad de haces. También se apreciaron líneas de replanteo para la colocación de las hiladas y tendeles de la sillería.
Referente al interior del muro este (UEC 17) se produce la modificación de su vano (UEC 18), con la sustitución de las posibles saeteras defensivas por un ventanal "embellecido" de estilo mudéjar. Según nuestra opinión, se sustituyeron los muros abocinados de la ventana por un hueco recto (luz de 1,47 m.) con jambas de sillarejos escuadrados perfectamente careados de los que apenas se conservan dos testigos. Las hiladas superiores del riñón del arco del vano son sillares escuadrados de medidas regulares trabados con mortero de cal. Sobre las jambas se desarrolla un doble arco rebajado realizado con ladrillos macizos formando una pequeña bóveda. Aparece el primer arco retranqueado, haciendo un sutil juego de sombras, que dan a la ventana una mayor profundidad. Las escopetas del plano del arco son de, aproximadamente, unos 0,04 $\mathrm{m}$. Este arco descansa sobre unos tímpanos realzados con sillarejos escuadrados que descansan sobre los riñones del arco. De carácter meramente decorativo intenta conseguir, mediante un rehundido de parte del tapial, más profundidad al arco y la sensación de una mayor dimensión del mismo jugando con un segundo plano. Sobre la arcada inferior se de- 


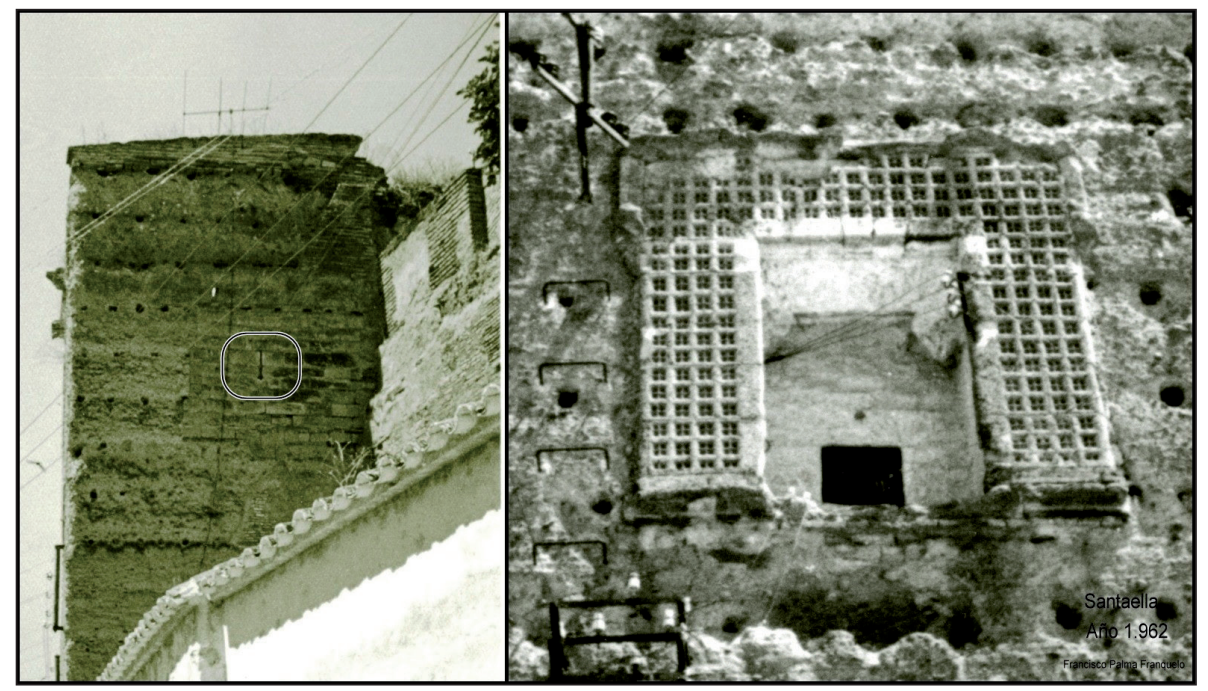

Fig. 15. Fotografía de 1962, donde se señala la saetera que había al exterior de la cara norte de la torre (izda.). Imagen de 1970 con detalle de las "galletas renacentistas" de la ventana recayente a la plaza de la cara sur de la torre (dcha.). (Fotografías de Francisco Palma Franquelo).

sarrollan dos hiladas de ladrillo horizontales, que se disponen a modo de marco superior de un posible recercado. Estas hiladas ornamentales marcan, así mismo, la línea de ruptura del tapial que se horadó para la colocación de la doble arcada. Se revistió con una capa de enfoscado y capas de mortero de cal pintado en almagra, que recubren tanto el plano de intradós como la "archivolta" de ladrillo superior del arco de la ventana este.

El uso de la doble arcada de ladrillo es recurrente en la arquitectura islámica combinándolo tanto con sillería como tapial, aun cuando los modelos más conocidos presentan un grado de monumentalidad importante. Algunos ejemplos son la Puerta de las Columnas de la alcazaba de Málaga o la puerta de la mezquita-iglesia de Santa María de Niebla, entre otros. Las torres de tapial del siglo XII, de manera exclusiva en Andalucía y Extremadura, lucieron como recurso decorativo tiras o fajillas de ladrillo en ligero saledizo tendidas en horizontal en el cuerpo superior, en donde se llegan a dar ejemplos de uno a cinco listeles. El vano de entrada estaría flanqueado por piedra y situado en el mismo lugar que el actual, pero a una cota sustancialmente inferior. A la

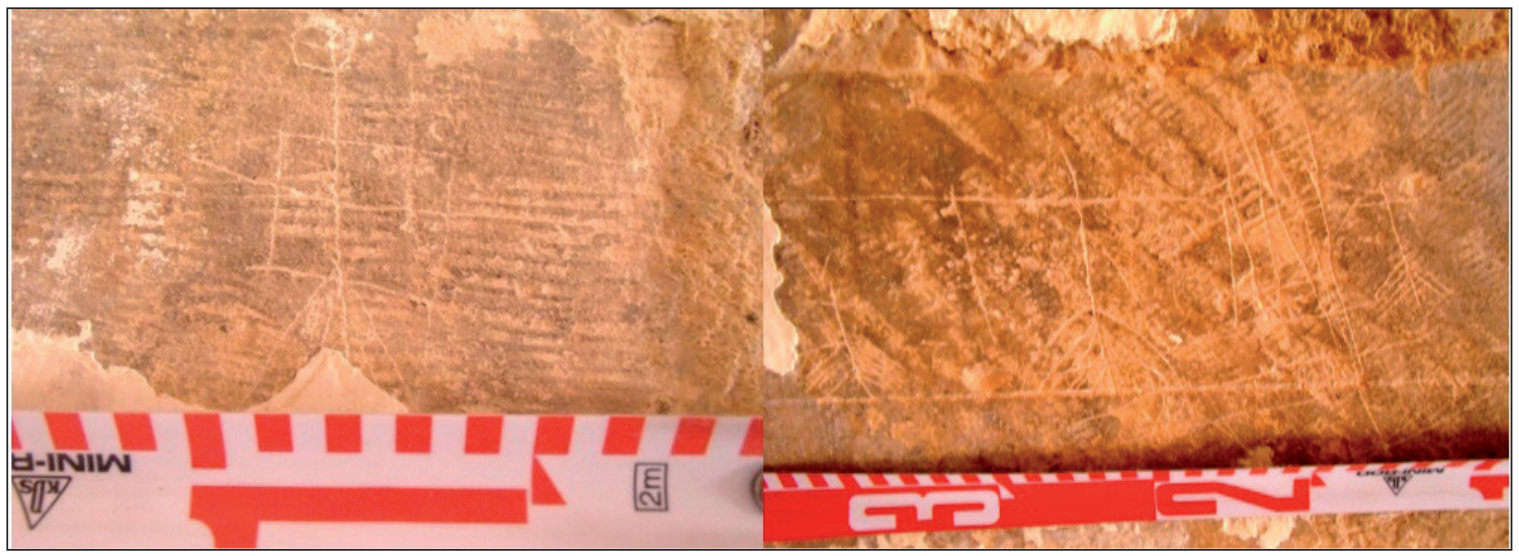

Fig. 16. Particular de los grafitis incisos localizados en la jamba derecha de la pared interior norte de la cámara. (RODERO, 2015). 
única sala se "accedería desde el adarve de la muralla... Se han cegado las ventanas que iluminaban la estancia interior, aunque es visible la forma del arco escarzano que remataría por el interior del ingreso a la sala principal, cuya bóveda cubierta se remata mediante una bóveda vaída de ladrillo" (LEÓN, 2003: 11).

Respecto a la cara interna del muro sur (UEC 19), la obra de sillería se reduce a la formación de la ventana sur (UEC 20) con una luz de 1,47 $\mathrm{m}$. Contiene jambas labradas en forma de paralelepípedo que encajan perfectamente entre ellas y traban con una cama de mortero de cal. Sobre esta sillería descansa un arco rebajado de ladrillo, mientras que al exterior (UEC 08) se aprecian las huellas del saqueo o desmonte de las dovelas del arco horizontal de la ventana primitiva. Es probable que la sillería en los vanos se redujera al refuerzo de las dos caras del vano interior y exterior, con sillares, dejando el interior vacío para encastrarlo rompiendo la tapia. Las dovelas fueron desmontadas para la colocación de la actual ventana renacentista. Existen en la actualidad dos estancias, una cuadrada principal, con dimensiones aproximadas de 4,09 × 3,95 m., y otra rectangular, de tamaño menor con 1,39 de ancho máximo y $3,61 \mathrm{~m}$. de longitud máxima, a las que se accedía, a través del vano situado en la esquina noroeste de la torre. Heredada de fines de la Baja Edad Media, supuso la colocación de un muro de separación que contribuyó a esa nueva distribución. Este murete soporta por medio de tendeles latericios sendas bóvedas, vaída y de aristas, una para la sala principal y otra para la antesala. Las diferentes reformas realizadas dentro de la cámara no afectaron al acceso original que siguió realizándose desde el paso de ronda por una puerta, cuyo umbral de piedra, apoyaba sobre el prístino nivel de suelo fundacional. Cortando por el interior los muros de tapial (UEC 15, 17, 19) y como cubierta de la estancia principal se coloca una bóveda (UEC 21), destinada a cubrir el espacio de planta cuadrangular de la cámara principal y dejando fuera la cubierta de la antesala oeste. Se construye un casquete semiesférico cuyas pechinas rompen los paramentos verticales de tapia para encajarse entre ellos. En este caso, la cúpula se forma a base de hiladas de ladrillo, probablemente colocados a bofetón, sin el uso de cimbras, siguiendo la tradición de algunos casos de la arquitectura andalusí (ALMAGRO, 2001: 153). La bóveda queda cerrada mediante clave de ladrillos y encajada con las pechinas de ladrillo entre los muros UEC 08, 09, 11 y el tabique de sillarejos UEC 13.

Por lo que respecta a la antesala, aparece cubierta con bóveda de arista (UEC 22). Este tipo de cubierta sigue la tradición de la arquitectura medieval andalusí ya que contiene enfoscado con mortero de cal y pintado en almagra (ver fig. 17). Este uso era muy extendido en Córdoba para diferentes ámbitos que abarcaban desde recintos militares hasta baños. Se ha llegado a conjeturar sobre el uso como caja de escalera de esta estancia. La constatación en las labores de documentación del macizado de la torre y la ausencia de un hueco para el terrado de la torre, complican en principio la asunción de dicha funcionalidad. El acceso a la cubierta de la torre sureste debía de hacerse por tanto desde el exterior y, como en tantas otras torres de similares características, con escaleras escamoteables (MÁRQUEZ, 2018: 5).

Podemos acercarnos a la cronología tectónica de las estructuras analizadas, a través de relaciones de anterioridad respecto a lo conocido del estado del castillo de Santaella en los siglos XV Y XVI. Como se ha plasmado en el contexto histórico, el periodo en que la fortaleza ejerció gran parte de su función defensiva tuvo lugar durante las disputas nobiliarias generadas al calor de las guerras civiles castellanas por el control de la monarquía, hasta la definitiva consolidación de la posición de los Reyes Católicos en 1478. Con este objetivo, el señor de Aguilar, se hace con el control de la plaza entre 1460-1469 pese a estar bajo el control del concejo de la capital. La villa se mantiene en pie y bajo control del señor de Aguilar en 1474 cuando "la ocupación de esta fortaleza por parte del bando del Conde de Cabra conllevó la reparación de los desperfectos causados durante el asedio de 1474. Resulta probable que en este periodo se llevaran importantes obras en el conjunto, acaso el alambor de sillería junto a 
la Torre del Homenaje" (LEÓN, 2003: 25). Esto coincide, como ya se indicó, con la petición del mariscal de Castilla, en febrero de 1478, sobre que se le reembolsase el dinero gastado en el castillo. Al mismo tiempo, también se ha manifestado en líneas anteriores, en una carta de 1523, que el Conde de Cabra hizo ciertas reformas en la fortaleza. Incluso menciona Béthencourt que el Alcaide de los Donceles, deseoso aún de poner la paz entre varones tan ilustres de una misma familia, trató desde Castro del Río con Alonso de Palencia y Pedro de la Grana, criados del mismo Duque de Medina, para que toda la gente saliese de Santaella, "quedando sólo allí Don Martín de Córdova con la suya, mientras se reparaba lo destrozado y además se daba libertad a Don Gonzalo Fernández y a los demás caballeros presos en Baena" (FERNÁNDEZ DE BÉTHENCOURT, 2001-2003: v.6, 88). La transición de la época bajomedieval a la moderna se documenta por medio de una capa de tierra que formaba parte de la preparación del suelo. Esta preparación se encuentra bajo los fragmentos de suelos localizados de los siglos XV-XVI y amortizando las pinturas originales de color almagra sobre el suelo de tapia tardoislámico (ver fig. 17).

\subsubsection{La fase moderna}

Los datos más relevantes del periodo moderno nos los muestra un conjunto de testigos de suelo asociados a esta fase de ocupación histórica. Se localizó, bajo el vano este (UEC 18) y en la esquina suroeste del vano sur (UEC 20), una cama de cal con fragmentos de cerámica, de unos $4 \mathrm{~cm}$ de grosor, que sirvió de firme al suelo propiamente dicho. El suelo presentaba un grosor de unos $2 \mathrm{cms}$. y se caracterizaba por lo depurado de su cal y el alisado de su acabado.

Lo más reseñable es la constatación en este suelo de ocupación de época moderna de un umbral principal desde el paso de ronda al interior de la cámara. Este paso de la puerta de acceso está formado por dos piezas de calcarenita. Se conserva una jamba de mampuestos trabados con mortero de cal del muro este de la puerta del periodo moderno.

El acceso desde el exterior del paso de ronda se haría, traspasando el umbral, por medio de una rampa descendente hacia el interior de la torre. Se trata de una capa en forma de cuña muy compacta que salva el desnivel del nuevo acceso desde la puerta a la cámara, lo que permitió utilizar el suelo original de época tardoislámica. La modificación de la cota de suelo viene condicionada por la transformación del nivel de suelo del exterior de la torre o de la plaza de armas, que se plasma con la colocación de una nueva grada en la puerta de acceso. Continuando la tradición de la decoración de la torre, se conservan vestigios de una banda de color almagra a modo de zócalo, en torno al cerramiento del vano norte (UEC 15). Estas capas de almagre cubrían la mitad supe-

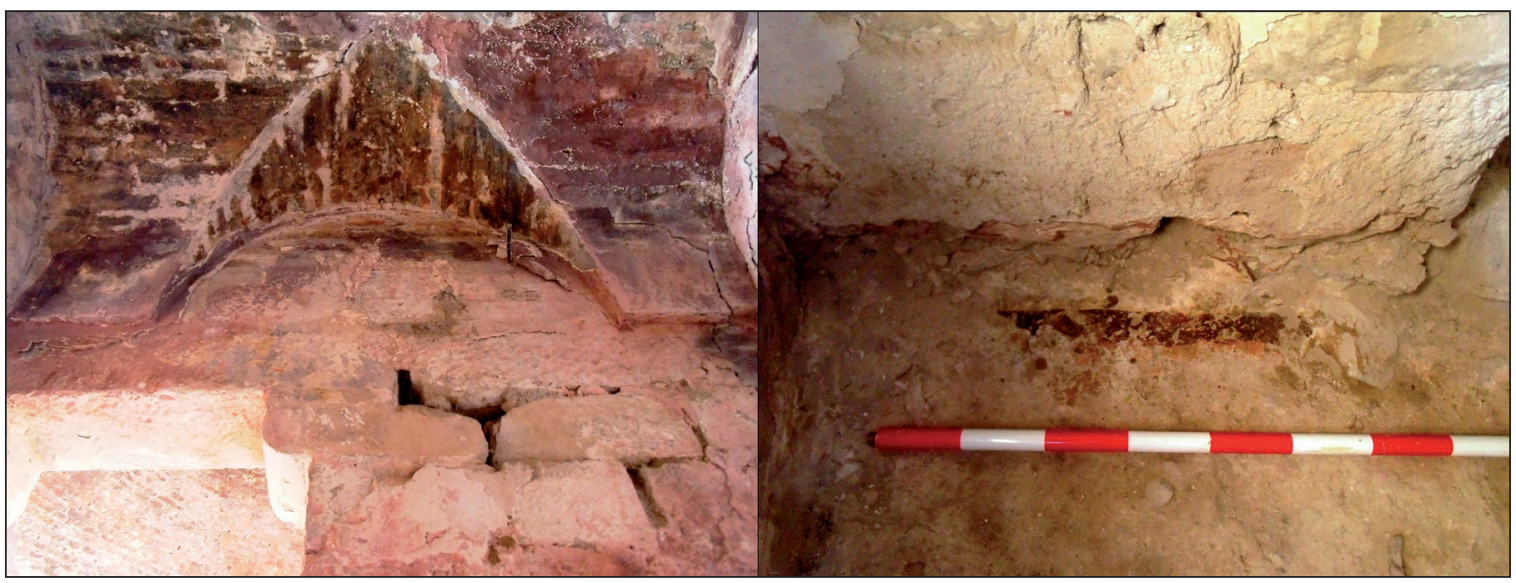

Fig. 17. Detalle de la bóveda de arista de la estancia menor apoyando sobre muro medianero de sillarejos (izda.). Detalle decorativo sobre el tapial tardoislámico a modo de "cinta de almagra" que definen el suelo original de la estancia (dcha.). (RODERO, 2015). 


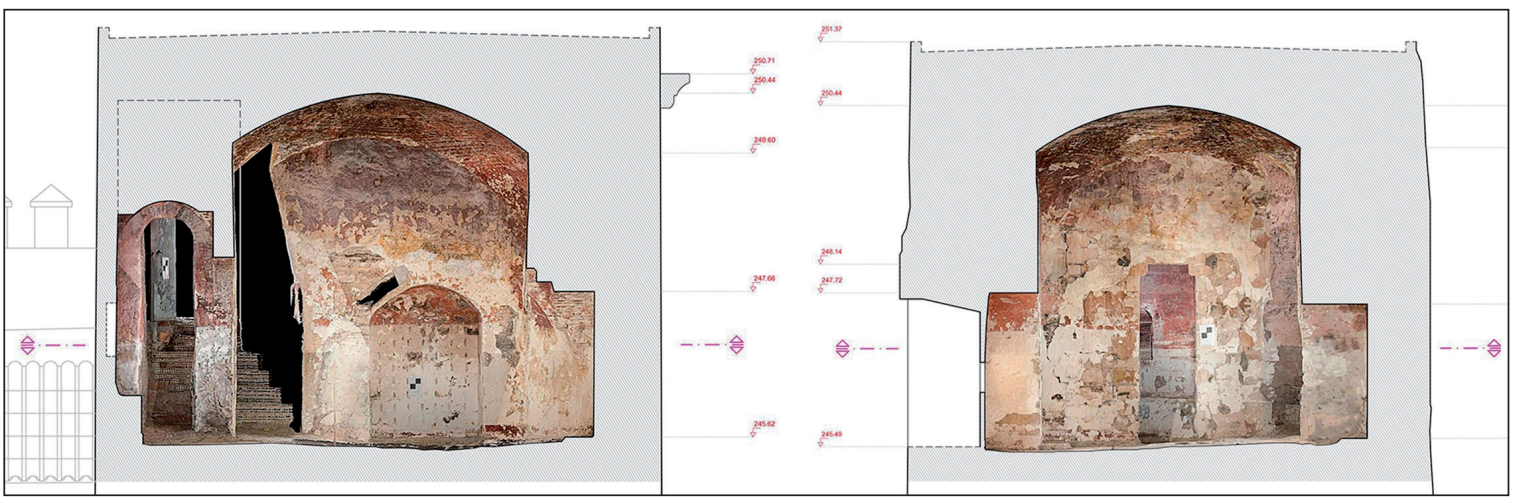

Fig. 18. Secciones de la cámara este-oeste (izda.) y norte-sur (dcha.) donde se puede apreciar el grosor de los muros de tapial originales y la bóveda mudéjar. (RODERO, 2015).

rior del muro sur (UEC 19), el intradós del arco del vano sur (EC 20) y un rodapié pintado por toda la estancia (ver fig. 17).

La última fase tectónica en este sector fue la que se realizó en tiempos de don Alfonso de Aguilar. Destaca por la colocación de un recercado de piedra en el vano sur, abierto a la plaza en su zona meridional y que no deja de ser un recurso estético como ventana a la modernidad. Para ello, se procedió a la rotura de la ventana adintelada de época bajomedieval de la torre, aún se conservaban las huellas del despiece del dovelaje del arco horizontal, para sustituirla por una celosía ciega, cuadrangular, que delimita una ventana renacentista (UEC 24). Esta ventana se presenta con un gran vano recto, con un marco característico con casetones o "galletas" bajo arrabá de molduración gótica (ver fig. 15). Atribuido a uno de los Hernán Ruiz, este cuadriculado de las portadas, a través del rehundido en el fondo y resalte de los lados, busca imitar un ajedrezado con el que rodea puertas y ventanas. Así se hizo en otros sitios de Córdoba como en la puerta del convento de la Madre de Dios (Baena, Córdoba); la casa del Aguilar, que se llamó del Gran Capitán (Córdoba); la de Sotomayor, hoy Conservatorio (Córdoba) y otra en la calle de Rey Heredia o en el crucero plateresco de la Mezquita (ambas en Córdoba). Esta generación de arquitectos, oriundos de Burgos, los Ruiz, fueron grandes maestros de obras que engrandecen a Córdoba. El segundo Hernán Ruiz, natural de Córdoba, imprime a sus obras un sello propio dentro del plateresco, que se conservó a través de los siglos (ORTí, 1961: 60).

Asistimos posteriormente, pero dentro del periodo moderno, a un intenso proceso de cerramiento de vanos mediante forros de sillarejos regulares de secciones trapezoidales y trabados con mortero de cal. En este momento, se produce el cegamiento mediante sillarejos del vano norte por el interior (UEC 25) y el cerramiento de la ventana este con un tabique de sillarejos cuadrados (UEC 23). Como se ha señalado anteriormente, el tránsito del periodo bajomedieval a la modernidad, se caracterizó por acontecimientos convulsos que sufrió la fortaleza santaellense. El siglo XV, como se ha detallado en el apartado histórico, el castillo estará en poder de don Alfonso Fernández de Córdoba. La lucha de los bandos nobiliarios con la sucesiva posición de partidarios de Enrique IV como del infante Alfonso, harán que este fortín sufra determinados avatares, que provocaron su deterioro hasta el punto que necesitó de múltiples reparaciones. Fernández de Béthencourt nos informa que las personas que residían en la villa de Santaella debían salir de la misma, quedando únicamente el ya citado alcaide de los Donceles mientras se reparaba (FERNÁNDEZ DE BÉTHENCOURT, 2001-2003: vol. 6, 88). Unas obras que, como se ha visto a través de la real cédula de los Reyes Católicos de febrero de 1478 y la carta posterior de 1523, fueron llevadas a cabo por el Conde de Cabra. 


\subsubsection{El periodo contemporáneo}

Entre la modernidad y la edad contemporánea, surgen abundantes materiales cerámicos y constructivos de relleno de una pequeña fosa documentada en la torre. De cronología ignota, debemos mencionar la existencia de una capa de hollín, que afectaba directamente al encerado de tapial; este encerado se conservó como tratamiento epidérmico interior desde el origen de la torre. Las huellas de calcinado nos acercan al horizonte de abandono de la cámara, cuando era habitual el uso de lumbres y hogares al interior de la torre, o cuando la edificación experimentó diferentes procesos luctuosos. Se comprobó la presencia de superposiciones de enfoscados de mortero rosa e incluso reparaciones con emplastes de paja, arena y cal. Otro de los cambios estéticos realizados en este momento consistió en la colocación de una doble ventana en el paramento oeste, así como, la superposición de diferentes capas de morteros y enfoscados. La instalación de la doble ventana UEC 26 se realizó rompiendo el muro (UEC 13) y colocando ladrillos macizos de canto trabados con cemento. En la actualidad, estas ventanas geminadas de carácter historicista, aparecen cegadas y enfoscadas en rojo, sin poder aseverar que en su día estuvieran abiertas (ver fig. 19). Por último, al final de este periodo se asiste al saqueo y despiece de parte de los sillares que formaban las jambas de los vanos este y norte de su fase bajomedieval cristiana.

\section{CONCLUSIONES}

La intervención realizada en el interior de la torre sureste del castillo de Santaella, destaca por la presencia de ocupación a lo largo de los siglos medievales, en concreto, desde época almohade, periodo cristiano y hasta la contemporaneidad. El periodo almohade nos aporta la técnica constructiva original de la torre realizada con cajas de tapial enriquecido sobre un bloque prismático de tapia que apoya en una doble zarpa de cantería. A esta datación se adscribe el nivel de suelo original que conserva restos de pintura decorativa en almagre, así como dos huecos que definen suelos de ocupación. Fruto de la importancia histórica de la villa de Santaella y su fortaleza como elemento defensivo, el periodo bajomedieval muestra las estructuras documentadas en el interior de la torre sureste que definen un sustancial momento constructivo. Si la fase precedente es el origen, en este momento se parte del aprovechamiento de estructuras subyacentes, con la instalación de un nuevo paño murario, el fortalecimiento de otros existentes y el uso de la sillería y ladrillo para los vanos como característica principal. Se aprecia en este proceso, la asunción de todo un programa edilicio mudéjar dirigido por un alarife con claras premisas constructivas. Asistimos a la compartimentación del espacio original, a través de un muro con vano adintelado y la colocación de nuevas cubiertas, consistente en una bóveda baída por un lado y una bóveda arista por otro.

Sin duda alguna, la llegada de la modernidad supuso el abandono y declive de la fortaleza y el inicio de un proceso de saqueo y desmonte que ha llegado prácticamente hasta hace unas décadas. Es el momento de la última fase tectónica en este sector, que, como no podía ser de otra manera, fue la que se realizó previsiblemente en tiempos de la Casa de Aguilar. Esta destaca principalmente por la colocación de un recercado de piedra con casetones o "galletas" renacentistas en el vano sur; abierto a la plaza y que no deja de ser un recurso estético de aquellos momentos.

El saqueo del conjunto defensivo por parte de los vecinos, desde al menos fines del siglo $\mathrm{XV}$, como demuestran las fuentes documentales bajomedievales, tiene un fuerte impacto en el entramado arquitectónico, del cual aquellos se aprovisionan del material ya trabajado para mejorar sus viviendas y edificios públicos. A consecuencia de ello, se desmontan estructuras y arrasan revestimientos de la torre, del recinto amurallado y del castillo, hasta extraer los ripios de los migajones o rellenos constructivos. El saqueo organizado tiene su muestra más evidente en la jamba derecha del vano de entrada o en los vanos norte y este. En ella se aprecia cómo desmontan los revestimientos 


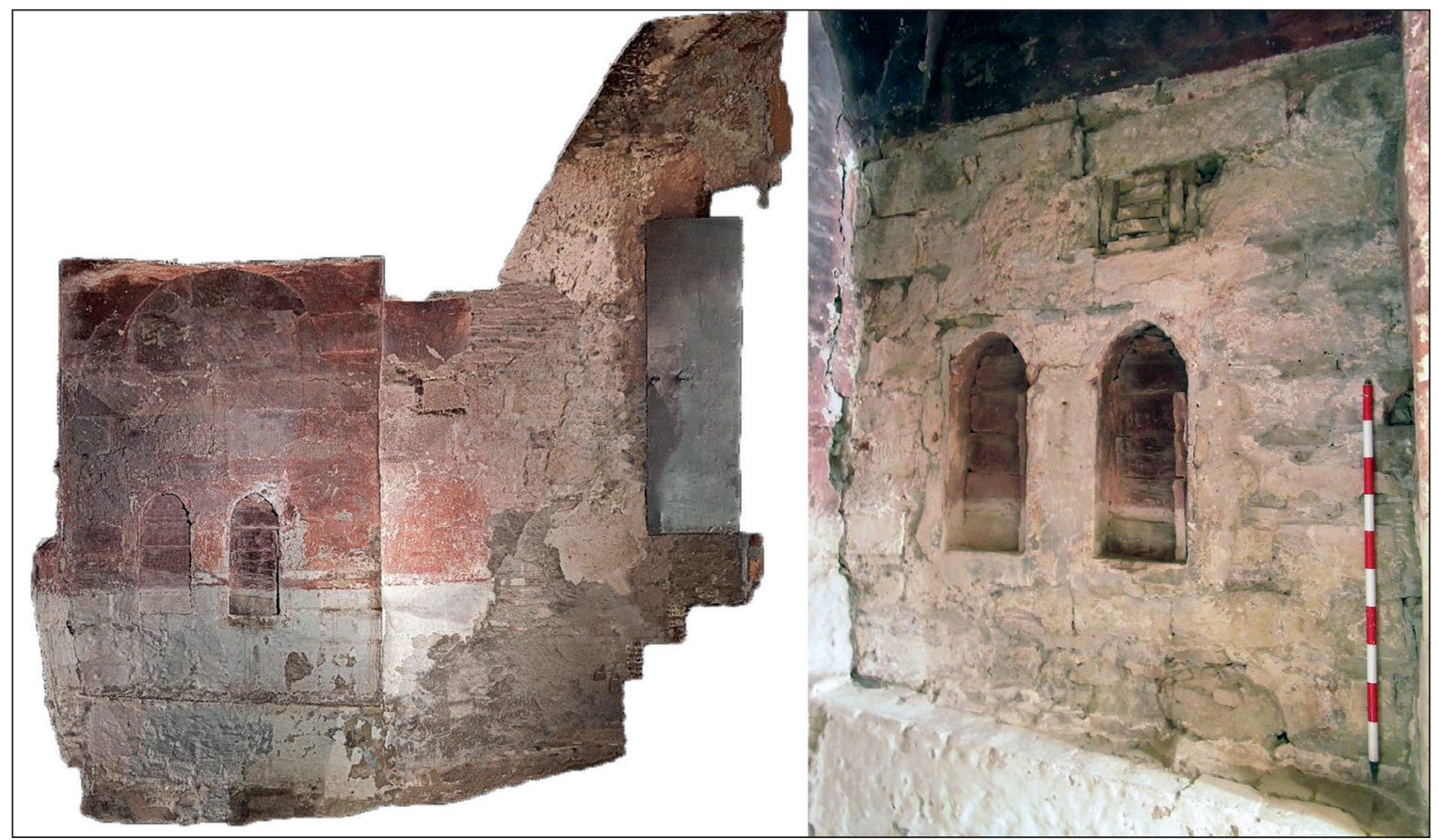

Fig. 19. Sección de la cámara desde el vano de acceso hacia el muro sur (izda.). Perspectiva de las ventanas geminadas de época contemporánea en muro UEC 13 (dcha.). (RODERO, 2015).

de este muro hasta su núcleo interno. Durante los siglos XIX Y XX, la torre, que no castillo puesto que hace tiempo que dejó de existir, se mantuvo en un mismo nivel de dejadez y degradación, sirviéndose el municipio de ella según las necesidades que iban sucediéndose. Actuaciones estas que se dejan entrever en las propias Actas Capitulares del concejo de Santaella, como en 1882 donde el alcalde hizo presente la necesidad de edificar un cobertizo al muro de contención del castillo, por bajo de la línea de explanación de aquel. La necesidad de esta obra, era provocada por las humedades que se absorbían y se extendían por las bóvedas de la torre, amenazando su solidez. Incluso, el alcalde de este momento, señaló que "el edificio no merece que se destine cantidad alguna para su conservación por no ser suficiente a contener las oficinas" (LÓPEZ, 2015b: 12). Consecuentemente, este espacio se convierte, en un primer momento de abandono en un hábitat domestico de carácter lumpénico, asistiéndose en el siglo XX a la reparación somera de alguno de sus muros y enfoscados, optimizando el aprovechamiento del espacio cubierto. Se usó también como estancia para estabular animales y como palomar, de todo lo cual han quedado huellas en sus muros y suelo.

De todo esto, se concluye la ocupación ininterrumpida en el interior de la torre del castillo desde, al menos, época tardoislámica hasta la actualidad, superando gran cantidad de avatares, ha llegado, afortunadamente, hasta nosotros dando muestras de la importancia patrimonial de sus muros y estructuras. Se puede comprobar que el castillo de Santaella ha sido muy importante para el ámbito militar, sobre todo por su carácter defensivo. El motivo de su creación fue la protección de los vecinos de la villa santaellense, así como para respaldar el enfrentamiento fronterizo entre cristianos y musulmanes. Una vez que esta función dejó de ser tan necesaria, comenzó a destruirse, puesto que en los años veinte del siglo XVI ya se encontraba solamente con la torre y el adarve que hoy día se puede apreciar.

Gracias a la correcta planificación de la intervención arqueológica y a las fuentes documentales inéditas aquí analizadas, se demuestra una vez más que el fin de la vida de un 
castillo es la pérdida de su utilidad originaria y primitiva, siendo su ocaso el derribo directo o paulatino. Un ejemplo de ello, lo acabamos de evidenciar en el castillo de Santaella, que desde la segunda mitad del siglo XV fue perdiendo su entidad militar, no reparándose, reutilizando sus materiales, pasando de ser un castillo a solo un torreón defensivo con ciertos lienzos de muralla, que es lo que queda en nuestros días.

\section{BIBLIOGRAFÍA}

AL-IDRISI (1989): Los caminos de Al-Ándalus en el siglo XII, Madrid, CSIC.

AL-IDRISI (2009-2010): Descripción de España: (obra del siglo XII), Imprenta y Litografía del Depósito de Guerra, 1901, copia digital de la Junta de Castilla y León.

ALMAGRO GORBEA, Antonio (2001): "Un aspecto constructivo de las bóvedas en al-Andalus", Al-Qantara: Revista de estudios árabes, 22-1, 147-170.

ANDRÉS TOBAR, Antonio Fray (1951): "Documentos originales de los Reyes Católicos en archivos particulares (1485-1515)", Revista de Archivos, bibliotecas y museos, tomo LVII, 3, 637-656.

ARJONA CASTRO, Antonio (1982a): Anales de la Córdoba musulmana (711-1008), Córdoba, Monte de Piedad y Caja de Ahorros.

ARJONA CASTRO, Antonio (1982b): El Reino de Córdoba durante la dominación musulmana, Córdoba, Diputación Provincial.

BASCÓN MATEOS, José Miguel (2018a): Memoria final de resultados Actividad Arqueológica Previa control arqueológico de movimientos de tierras "Restauración natural del entorno del casco histórico de Santaella (Córdoba)". Memoria inédita. Delegación Provincial de Cultura de la Junta de Andalucía en Córdoba.

BASCÓN MATEOS, José Miguel (2018b): Memoria final de resultados Actividad Arqueológica Puntual "Patio de armas del castillo de Santaella (Córdoba)". Memoria inédita. Delegación Provincial de Cultura de la Junta de Andalucía en Córdoba.

BELTRÁN FORTES, José y MORA SERRANO, Bartolomé (2000): "Antigüedades romanas de Santaella (Córdoba), a partir de los datos contenidos en una carta del siglo XVIII", Anuario arqueológico de Córdoba, 11, 13-31.

BELLIDO MÁRQUEZ, Tania (2008): "Análisis estratigráfico en la muralla medieval de Marchena (Sevilla)", Arqueología de la Arquitectura, 5, 159-185.

CABRERA MUÑOZ, Emilio (1976-1977): "El problema de la tierra en Córdoba a mediados del siglo XIV”, Cuadernos de Estudios Medievales, IV-V, 41-71.
CABRERA MUÑOZ, Emilio (1995): "Reconquista, organización territorial y restauración eclesiástico en el reino de Córdoba”, en Fernando III y su época. Actas de las IV Jornadas Nacionales de Historia Militar, Sevilla, Cátedra General Castaños and Diputación Provincial, 313-334

CABRERA SÁNCHEZ, Margarita (1996): "Los regidores de Córdoba en 1480. Aproximación prosopográfica”, Meridies. Revista de historia medieval, 3, 61-88.

CARPIO DUEÑAS, Juan Bautista (2001): "Poder político y poder militar: los castillos de la "tierra de Córdoba". 1478", en HUERTA HUERTA, Pedro Luis (Coord.), Actas del IV Curso de Cultura Medieval: Seminario la fortificación medieval en la Península Ibérica, Aguilar del Campoo, Centro de Estudios del Románico y Fundación Santa María la Real, 21-26 de septiembre de 1992, 229-235.

CASTEJÓN, Rafael (1961-1962): "Excavaciones en el Alcázar de los califas”, Al-Mulk, 2, 240-253.

CÓRDOBA DE LA LLAVE, Ricardo (2004): "Fortificaciones almohades de la provincia de Córdoba”, en VALOR PIECHOTTA, Magdalena (Coord.), Los almohades. Su patrimonio arquitectónico y arqueológico en el sur de al-Andalus, Sevilla, Consejería de Relaciones Institucionales, 123-129.

COSTAS RODRÍGUEZ, Jenaro (2001): Fernando III a través de las crónicas medievales, Zamora, Excelentísimo Ayto. y Centro de la UNED.

DEL PULGAR, Fernando (1953): Crónica de los señores Reyes Católicos, Madrid, edit. BAE.

ESLAVA GALÁN, Juan (1989): "Fortificaciones de tapial en Al-Andalus y Al-Magreb",

Castillos de España. Boletín de la Asociación Española de Amigos de los Castillos, vol. 96, 52-55.

FERNÁNDEZ DE BÉTHENCOURT, Francisco (2001-2003): Historia genealógica y heráldica de la monarquía española, Casa Real y Grandes de España, 10 vols., Sevilla, Fabiola de Publicaciones Hispalenses.

FERNÁNDEZ GONZÁLEZ, Rafael (1964): "El castillo de Luque", Boletín de la Real Academia de Córdoba de Ciencias, Bellas Letras y Nobles Artes, 86, 197-226.

GARRIDO GONZÁLEZ, Pablo (2017): Análisis de estructuras emergentes y control arqueológico de movimiento de tierra para las obras de restauración del lienzo de muralla sur y construcción de un acceso al torreón del castillo de Santaella. Informe Administrativo inédito. Delegación Provincial de Cultura de la Junta de Andalucía en Córdoba.

GAZTELU, Luis (1899): Fábricas en General, Madrid, Librería Editorial De Bailly-Bailliere e hijos.

GIL CRESPO, Ignacio y MALDONADO RAMOS Luis (2015): "Hacia una taxonomía constructiva de las tapias de tierra y fábricas encofradas históricas", Informes de la Construcción, 67 (538), e086. DOI: http://informesdelaconstruccion.revistas.csic.es/index.php/informesdelaconstruccion/article/view/4226/4882 
GONZÁLEZ JIMÉNEZ, Manuel (1991): Diplomatario andaluz de Alfonso X, Sevilla y Huelva, El Monte.

GODOY DELGADO, Francisco (1987): "Excavación arqueológica de urgencia en el yacimiento de "La Calva", Santaella (Córdoba)", Anuario arqueológico de Andalucía, III, 127-131.

GRACIANI, Amparo (2008-2009): "Fábricas islámicas del mirador almohade de la Muralla de Marchena (Sevilla). Tramos de la Alcazaba y el parque", Laboratorio de Arte: Revista del Departamento de Historia del Arte, 21, 13-35.

GRACIANI, Amparo (2009): "La técnica del tapial en Andalucía Occidental”, en SUÁREZ MÁRQUEZ, Ángela (Coord.), Construir en al-Andalus, Junta de Andalucía, Conserjería de Cultura, 111-140.

GURRIARÁN DAZA, Pedro y SÁEZ RODRÍGUEZ, Ángel J. (2002): "Tapial o fábricas encofradas en recintos urbanos andalusíes", en Actas del II Congreso Internacional La ciudad en Al-Andalus y el Magreb, Fundación el Legado Andalusí, Granada, 561-625.

IBÁÑEZ CASTRO, Alejandro (1993): Intervención Arqueológica de apoyo a la restauración de la lglesia parroquial de Ntra. Sra. de la Asunción de Santaella. Fase II, Conserjería de Cultura de la Junta de Andalucía, Exp. 439, Consejería de Cultura.

LEÓN MUÑOZ, Alberto (1999): "Los castillos en el reino de Córdoba: revisión historiográfica y perspectivas actuales", Anales de arqueología cordobesa, 10, 291-336.

LEÓN MUÑOZ, Alberto (2003): Documentación técnica para el expediente de declaración de BIC del Castillo y recinto amurallado de Santaella, Expte. 163/2005/seb. Delegación Provincial de Cultura de la Junta de Andalucía en Córdoba.

LEÓN MUÑOZ, Alberto; MURILLO REDONDO, Juan Francisco; GARCÍA MATAMALA, Begoña y PIZARRO BERENGENA, Guadalupe (2004): "Informe-memoria de la intervención arqueológica de urgencia en el P.A. SS-4 (entorno de la Torre de la Calahorra)", Anuario Arqueológico de Andalucía 2001, 3-1, 244-257.

LEÓN MUÑOZ, Alberto (2009): "Las fortificaciones castellanas del siglo XV en el reino de Córdoba”, Actas I Jornadas de Fortificaciones Medievales: El sur de Córdoba, Córdoba, del 28 de septiembre al 3 de octubre de 2009, Ayto. de Aguilar de la Frontera, 59-111.

LÓPEZ GARCÍA, José Antonio (2018): Análisis de estructuras emergentes y control arqueológico de movimientos de tierra para las obras de restauración del Torreón del Castillo de Santaella (Córdoba). Memoria inédita. Delegación Provincial de Cultura de la Junta de Andalucía en Córdoba.

LÓPEZ PALOMO, Luis Alberto (1986): "Aportaciones a la Prehistoria y protohistoria de Santaella", en ARANDA DONCEL, Juan et alii, Santaella. Estudios históricos de una villa Cordobesa, Montilla, Círculo de Labradores: 11-40.

LÓPEZ PALOMO, Luis Alberto (1987): Santaella. Raíces históricas de la Campiña de Córdoba, Córdoba, Diputación Provincial.
LÓPEZ RIDER, Javier (2013): Estudio sobre construcciones hidráulicas e industriales de Santaella (Córdoba), Córdoba, Diputación Provincial.

LÓPEZ RIDER, Javier (2015a): "El gasto municipal de los concejos castellanos a fines de la Edad Media: el caso de Córdoba en la segunda mitad del siglo XV (14521500)", Historia. Instituciones. Documentos, 42, 199-239.

LÓPEZ RIDER, Javier (2015b): "Estudio histórico del Castillo de Santaella”, en RODERO PÉREZ, Santiago (2015), Memoria-preliminar de resultados de la Actuación Arqueológica Puntual previa a la restauración de la torre sureste del Castillo de Santaella (Córdoba). Parte III. Memoria inédita. Delegación Provincial de Cultura de la Junta de Andalucía en Córdoba.

LÓPEZ RIDER, Javier (2016), "Notas sobre el castillo de Santaella en la Baja Edad Media", Revista de Feria Real de Santaella, Córdoba, Diputación Provincial, 23-45.

LÓPEZ RIDER, Javier (2017): Santaella y el suroeste de la Campiña cordobesa en la Baja Edad Media, 2 vols., Córdoba, Colección tesis doctorales del Repositorio de Helvia de la Universidad de Córdoba.

LÓPEZ RIDER, Javier (2018a): "Los Fernández de Córdoba y el castillo de Santaella (Córdoba). Una muestra de enfrentamiento familiar en la segunda mitad del siglo XV", en Los Fernández de Córdoba: nobleza, hegemonía y fama. Homenaje a Manuel Peláez del Rosal, Jaén, Ayto. Alcalá la Real y Diputación Provincial, 281-292.

LÓPEZ RIDER, Javier (2018b): "Organización y configuración territorial del reino de Córdoba en tiempos de Alfonso X (1252-1284)", Norba. Revista de Historia, 31, 97-118.

MALPICA CUELLO, Antonio (2003): "Castillos y organización del territorio en Al-Andalus", en Andalucía medieval: actas del III Congreso de Historia de Andalucía, Córdoba, Obra Social y Cultural Cajasur, vol. 5, 17-46.

MÁRQUEZ BUENO, Samuel y GURRIARÁN DAZA, Pedro (2008): "Recursos formales y constructivos en la arquitectura militar almohade de al-Andalus", Arqueología de la Arquitectura, 5, 115-134.

MÁRQUEZ BUENO, Samuel (2018): "La tecnología constructiva andalusí: obra encofrada y revestimientos en la arquitectura militar (ss. XI-XIII). El ejemplo de las torres", Arqueología de la arquitectura, 15, 1-33.

MAZO ROMERO, Fernando (1974): "Los Suárez de Figueroa y el señorío de Feria", Historia. Instituciones. Documentos, 1, 111-164.

MILETO, Camilla y VEGAS, Fernando (2003a): "Adaptaciones metodológicas en la aplicación del análisis estratigráfico constructivo: el Santuario de San Juan de la Penyagolosa (Castellón) y la iglesia de San Juan de los Reyes en Granada", Arqueología de la arquitectura, 2, 197-204.

MILETO, Camilla y VEGAS, Fernando (2003b): "El análisis estratigráfico constructivo como estudio previo al proyecto de restauración arquitectónica. Metodologia y aplicación", Arqueología de la Arquitectura, 2, 189-196. 
MORENA LÓPEZ, José Antonio, LEÓN MUÑOZ, Alberto y RODERO PÉREZ, Santiago (2007): El castillo de Cañete de las Torres: una aproximación desde la historia y la arqueología, Ayto. de Cañete de las Torres.

NIETO CUMPLIDO, Manuel (1984): Islam y cristianismo, Córdoba, Monte de Piedad y Caja de Ahorros.

NIETO CUMPLIDO, Manuel (1986): "Santaella en la Edad Media”, en ARANDA DONCEL, Juan et alii, Santaella. Estudios históricos de una villa Cordobesa. Montilla, Círculo de Labradores, 41-83.

ORTÍ BELMONTE, Miguel A. (1961): "La ciudad antigua de Córdoba", Boletín de la Real Academia de Córdoba de Ciencias, Bellas Letras y Nobles Artes, 81, 53-70.

PAVÓN MALDONADO, Basilio (2012): "Murallas de tapial, mampostería, sillarejo y ladrillo en el Islam occidental (los despojos arquitectónicos de la Reconquista. Inventario y clasificaciones)", en PAVÓN MALDONADO, Basilio, Artículos y textos inéditos en línea: http://www. basiliopavonmaldonado.es/public/ineprueba.htm. [fecha de consulta: 20 de mayo de 2019].

QUINTANILLA RASO, María de la Concepción (1979): Nobleza y señoríos en el reino de Córdoba. La Casa de Aguilar (siglos XIV-XV), Córdoba, Monte de Piedad y Caja de Ahorros.

RAMÍREZ DE ARELLANO Y DÍAZ DE MORALES, Rafael (1919): Historia de Córdoba desde su fundación hasta la muerte de Isabel la Católica, vol. IV. Ciudad Real, Hospicio Provincial.

RAMÍREZ DE LAS CASAS DEZA, Luis María (1986): Corografía histórico-estadística de la provincia y obispado de Córdoba, Córdoba, Montes de Piedad y Caja de Ahorros.
REJÓN DE SILVA, Diego Antonio (1788): Diccionario de las nobles artes: contiene todos los términos y frases facultativas de la pintura, escultura, arquitectura y grabado y los de la albañilería o construcción, carpintería de obras de fuera, montea y cantería etc. con sus respectivas autoridades sacadas de autores castellanos según el método del Diccionario de la Lengua Castellana compuesto por la Real Academia Española. Segovia, Imprenta de Don Antonio Espinosa.

RODERO PÉREZ, Santiago (2015): Memoria-preliminar de resultados de la Actuación Arqueológica Puntual previa a la restauración de la torre sureste del Castillo de Santaella (Córdoba). Memoria inédita. Delegación Provincial de Cultura de la Junta de Andalucía en Córdoba.

RUANO, Francisco (1994): Casa de Cabrera en Córdoba: obra genealógica histórica. Escrita por el padre Ruano y publicada en 1779, Córdoba, Diputación Provincial.

RUFO ISERN, Paulina (1993): Documentación andaluza en el Registro General del Sello (1463-1482), Sevilla, Universidad.

SÁNCHEZ, José María y VALOR PIECHOTTA, Magdalena (2004): El castillo de Cortegana, Cortegana (Huelva), Asociación Amigos del Castillo de la Villa de Cortegana.

SARAZA MURCIA, Antonio (1935): Por tierras de Andalucía. La provincia de Córdoba, Córdoba, Imprenta Provincial.

VALVERDE CANDIL, Mercedes y TOLEDO ORTIZ, Felipe (1985): Los castillos de Córdoba, Córdoba, Caja Provincial de Ahorros y Asociación de Amigos de Córdoba.

VAQUERIZO GIL, D., "Sensacional hallazgo. Una tumba con ajuar campaniforme", Revista de Arqueología, 69 (1987), pp. 60-61. 
